GÖTTINGER ZENTRUM

FÜR BIODIVERSITÄTSFORSCHUNG UND ÖKOLOGIE

- Göttingen Centre for Biodiversity ANd ECology -

\title{
Below- and aboveground farmland biodiversity in relation to local and regional management
}

\author{
Dissertation zur Erlangung des Doktorgrades der \\ Mathematisch-Naturwissenschaftlichen Fakultäten der \\ Georg-August-Universität Göttingen
}

vorgelegt von

Diplom-Biologe

Andreas Flohre

aus

Ostercappeln

Göttingen, April, 2010 
Referentin/Referent:

Prof. Dr. Teja Tscharntke

Korreferentin/Korreferent:

Prof. Dr. Stefan Vidal

Tag der mündlichen Prüfung: 6.5.2010

CONTEnTs 
Chapter 1: General Introduction: Below- and aboveground farmland biodiversity in relation to local and regional management

Introduction

Chapter outline and hypotheses

References

Chapter 2: Agricultural intensification and biodiversity partitioning across European landscapes comparing plants, carabid beetles and birds

$\begin{array}{ll}\text { Abstract } & 15\end{array}$

$\begin{array}{ll}\text { Introduction } & 16\end{array}$

$\begin{array}{lr}\text { Methods } & 17\end{array}$

$\begin{array}{lr}\text { Results } & 22\end{array}$

Discussion
25

$\begin{array}{lr}\text { Acknowledgements } & 28\end{array}$

$\begin{array}{lr}\text { References } & 29\end{array}$

$\begin{array}{lr}\text { Appendix } & 37\end{array}$

Chapter 3: Does soil biota benefit from organic farming in complex vs. simple landscapes? 47

$\begin{array}{ll}\text { Abstract } & 48\end{array}$

$\begin{array}{ll}\text { Introduction } & 49\end{array}$

$\begin{array}{lr}\text { Material and Methods } & 50\end{array}$

Results

Discussion $\quad 55$

Acknowledgements $\quad 56$

$\begin{array}{lr}\text { References } & 56\end{array}$

Appendix

Chapter 4: Spatial scale predicts the distribution of soil biota: a community approach 64

$\begin{array}{lr}\text { Abstract } & 65\end{array}$

$\begin{array}{ll}\text { Introduction } & 66\end{array}$

$\begin{array}{lr}\text { Material and methods } & 68\end{array}$

$\begin{array}{ll}\text { Results } & 71\end{array}$

$\begin{array}{ll}\text { Discussion } & 73\end{array}$

$\begin{array}{ll}\text { Acknowledgments } & 76\end{array}$

$\begin{array}{ll}\text { References } & 76\end{array}$

$\begin{array}{lr}\text { Chapter 5: Synthesis } & 82\end{array}$

$\begin{array}{lr}\text { Summary } & 85\end{array}$

$\begin{array}{lr}\text { Acknowledgements } & \mathbf{8 8}\end{array}$

$\begin{array}{lr}\text { Curriculum Vitae } & 89\end{array}$ 
Declaration of the author's own contribution to manuscripts with multiple authors 
Chapter 1

GENERAL INTRODUCTION: BELOW- AND ABOVEGROUND FARMLAND BIODIVERSITY IN RELATION TO LOCAL AND REGIONAL MANAGEMENT 


\section{INTRODUCTION}

Biodiversity research has become a major topic in ecological research these days. Many studies were conducted to identify the main drivers for the loss of biodiversity (Foley et al. 2005), find appropriate measures to counteract (Bengtsson et al. 2005, Tscharntke et al. 2005) and link biodiversity to ecosystem functioning (Bell et al. 2005, Hooper et al. 2005, Loreau et al. 2001).

One of the main drivers of biodiversity loss is the expansion of global croplands, plantations and pastures in the last decades (Foley et al. 2005), which led to a dramatic change in the spatial structuring of agricultural landscapes. Diverse and highly complex agricultural landscapes were converted to simplified landscapes consisting mainly of intensively managed agricultural units (Benton et al. 2003, Robinson and Sutherland 2002). Intensified agriculture, e.g. increased use of agrochemicals, increased input of pesticides and fertilizers on a local scale and simplification of landscapes on a regional scale were accompanied by a dramatic loss of biodiversity in European agricultural landscapes (Bengtsson et al. 2005, Foley et al. 2005, Matson et al. 1997, Stoate et al. 2001). However, the relative importance of local and regional drivers differs between taxa and habitats (Dauber et al. 2005, Tscharntke et al. 2005). While effects of agricultural intensification have been a major topic in ecological research in the last decade, they have mainly been studied at the plot scale, although processes determining diversity operate at different spatial scales (Collins et al. 2002, Crawley and Harral 2001, Weiher and Howe 2003) and assessing diversity merely at one scale can be misleading (Tylianakis et al. 2006). For example, agricultural intensification could lead to a homogenization of communities on e.g. the field scale, which could have profound effects on the species turnover between fields and hence to species richness on larger scales.

Agri-environmental schemes aimed at counteracting detrimental effects of agricultural intensification, for example organic farming (Bengtsson et al. 2005, Hole et al. 2005), are hypothesized to be more efficient in simple landscapes compared to complex landscapes (Tscharntke et al. 2005). In complex landscapes the beneficial effects of AES are blurred by the overall higher biodiversity due to the higher amount of semi-natural habitats and environmental heterogeneity. This hypothesis is confirmed for plants (Roschewitz et al. 2005), pollinators (Holzschuh et al. 2007, Rundlof et al. 2008), spiders (Schmidt et al. 2005, 2008), carabid beetles (Purtauf et al. 2005) and butterflies (Rundlof and Smith 2006). Although belowground biodiversity is an important and integrative part of the agroecosystem, studies on the interacting effects of local and landscape intensification on bacteria, 
collembolans and earthworms, which are important belowground detritivores (van der Heijden et al. 2008, Jouquet et al. 2006, Rusek 1998) are lacking. Likewise studies on the effect of landscape complexity on belowground soil biota in general are scarce, while soil surface-inhabiting fauna, e.g. carabids and spiders have been studied (Ostman et al. 2001, Purtauf et al. 2005, Schmidt et al. 2005). Current knowledge on belowground biodiversity suggests that soil communities are highly resistant to anthropogenic disturbances due to the enormous functional redundancy in belowground food webs (Swift et al. 2004, Bardgett 2005, Fitter et al. 2005). Further, effects of agricultural intensification on belowground biota are not as predictable as effects on aboveground biota. For example, positive effects of organic farming on belowground decomposer diversity might only be evident years after the conversion from conventional farming to organic farming (Mader et al. 2002, Bardgett 2005, Birkhofer et al. 2008) and for soil communities confounding factors like soil type seem to be relatively more important than management (Bardgett 2005, van Diepeningen et al. 2006).

Community composition is one of the main drivers for ecological processes. The identity and abundance of species within communities can influence the rate and efficiency of ecosystem processes (Dangles and Malmqvist 2004, Wilsey and Potvin 2000, Wright et al. 2006), a pattern also observed in soil faunal and bacterial communities (Bradford et al. 2002, Scheu et al. 2002, Strickland et al. 2009).

Community composition is influenced by biotic as well as abiotic factors. The relative importance of environmental and spatial processes determines whether communities are mainly formed by species-environment interactions or dispersal events (Cottenie 2005, Freestone and Inouye 2006, Schweiger et al. 2005), as outlined in the metacommunity concept (Leibold et al. 2004, Loreau et al. 2003). The relative importance of environmental and spatial factors in determining community composition of bacteria is a topic under vivid debate during the last decade (Martiny et al. 2006). Historically, bacteria are presumed to disperse ubiquitous due to their smallness and fast generation times (Martiny et al. 2006). Although there is a growing number of studies showing spatial distance effects on bacterial distributions on continental or landscape wide scales, studies on small scales are rare. Soils are very patchy, complex and poorly connected habitats, so dispersal limitation might shape the community composition more strongly than in less complex and better connected habitats like streams or lakes. In soil, dispersal ability and mode might play a prominent role in explaining dispersal distance. Thus the mode of dispersal, be it either passive or active and 
the size of the dispersal unit are likely to be fundamental for understanding dispersal (Jenkins et al. 2007).

\section{CHAPTER OUTLINE AND HYPOTHESES}

In the present study we studied the effects of agricultural intensification on the spatial organization of plants, carabid beetles and birds in agricultural landscapes on different spatial scales (chapter 2). We analysed diversity at the field $(n=1350)$, farm $(n=270)$, and European region $(n=9)$ scale, partitioned diversity into its additive components $\alpha, \beta$, and $\gamma$, and assessed the relative contribution of $\beta$-diversity to total species richness at each spatial scale. Agricultural intensification was determined using pesticide and fertilizer inputs as well as tillage operations and categorized into low, medium and high levels. Further focal points are the effects of agricultural intensification on soil inhabiting faunal and bacterial communities (chapter 3). We sampled diversity and abundance of arable weeds, earthworms and collembolans, soil respiration rate and microbial biomass in 12 pairs of organically and conventionally managed fields in landscapes differing in structural complexity. Finally, we used a variance partitioning approach to investigate the relative importance of environmental conditions and spatial distances for soil bacterial, collembolan, carabid beetle and earthworm community composition in agricultural fields and old set-aside fallows, comparing samples from a very small scale of $40 \mathrm{~m}$ with samples from a regional scale of up to $13 \mathrm{~km}$ (chapter $4)$.

Our main hypotheses were:

(i) Agricultural intensification has a negative effect on species richness of plants, carabid beetles and birds, with $\beta$-diversity contributing most to total diversity (chapter 2).

(ii) Local agricultural intensification is not only related to local biodiversity losses, but also to losses at larger spatial scales (chapter 2).

(iii) Agricultural intensification reduces soil biota, but the effects should be less pronounced than effects on aboveground biota (chapter3).

(iv) Landscape simplification leads to reduced belowground soil biota (chapter 3).

(v) Even on small scales $(40 \mathrm{~m})$, soil bacterial communities are formed by a mixture of environmental and spatial drivers (chapter 4). 
(vi) The relative importance of environmental and spatial factors for soil community composition changes with average body size and dispersal ability of the considered taxa (chapter 4).

\section{REFERENCES}

Bardgett, R. D. 2005. The Biology of Soil: A community and ecosystem approach. Oxford University Press, Oxford.

Bell, T., J. A. Newman, B. W. Silverman, S. L. Turner, and A. K. Lilley. 2005. The contribution of species richness and composition to bacterial services. Nature 436:1157-1160.

Bengtsson, J., J. Ahnstrom, and A. C. Weibull. 2005. The effects of organic agriculture on biodiversity and abundance: a meta-analysis. Journal of Applied Ecology 42:261-269.

Benton, T. G., J. A. Vickery, and J. D. Wilson. 2003. Farmland biodiversity: is habitat heterogeneity the key? Trends in Ecology and Evolution 18:182-188.

Birkhofer, K., T. M. Bezemer, J. Bloem, M. Bonkowski, S. Christensen, D. Dubois, F. Ekelund, A. Fliessbach, L. Gunst, K. Hedlund, P. Mader, J. Mikola, C. Robin, H. Setala, F. Tatin-Froux, W. H. Van der Putten, and S. Scheu. 2008. Long-term organic farming fosters below and aboveground biota: Implications for soil quality, biological control and productivity. Soil Biology and Biochemistry 40:2297-2308.

Bradford, M. A., T. H. Jones, R. D. Bardgett, H. I. J. Black, B. Boag, M. Bonkowski, R. Cook, T. Eggers, A. C. Gange, S. J. Grayston, E. Kandeler, A. E. McCaig, J. E. Newington, J. I. Prosser, H. Setala, P. L. Staddon, G. M. Tordoff, D. Tscherko, and J. H. Lawton. 2002. Impacts of soil faunal community composition on model grassland ecosystems. Science 298:615-618.

Collins, K. L., N. D. Boatman, A. Wilcox, J. M. Holland, and K. Chaney. 2002. Influence of 
beetle banks on cereal, aphid predation in winter wheat. Agriculture Ecosystems \& Environment 93:337-350.

Cottenie, K. 2005. Integrating environmental and spatial processes in ecological community dynamics. Ecology Letters 8:1175-1182.

Crawley, M. J., and J. E. Harral. 2001. Scale dependence in plant biodiversity. Science 291:864-868.

Dangles, O., and B. Malmqvist. 2004. Species richness-decomposition relationships depend on species dominance. Ecology Letters 7:395-402.

Dauber, J., T. Purtauf, A. Allspach, J. Frisch, K. Voigtlander, and V. Wolters. 2005. Local Vs. Landscape Controls on Diversity: a Test Using Surface-Dwelling Soil Macroinvertebrates of Differing Mobility. Global Ecology and Biogeography 14:213221.

van Diepeningen, A. D., O. J. de Vos, G. W. Korthals, and A. H. C. van Bruggen. 2006. Effects of organic versus conventional management on chemical and biological parameters in agricultural soils. Applied Soil Ecology 31:120-135.

Fitter, A., C. Gilligan, K. Hollingworth, A. Kleczkowski, R. Twyman, and J. Pitchford. 2005. Biodiversity and ecosystem function in soil. Functional Ecology 19:369-377.

Foley, J. A., R. DeFries, G. P. Asner, C. Barford, G. Bonan, S. R. Carpenter, F. S. Chapin, M. T. Coe, G. C. Daily, H. K. Gibbs, J. H. Helkowski, T. Holloway, E. A. Howard, C. J. Kucharik, C. Monfreda, J. A. Patz, I. C. Prentice, N. Ramankutty, and P. K. Snyder. 2005. Global consequences of land use. Science 309:570-574.

Freestone, A. L., and B. D. Inouye. 2006. Dispersal limitation and environmental heterogeneity shape scale-dependent diversity patterns in plant communities. Ecology $87: 2425-2432$.

van der Heijden, M., R. Bardgett, and N. van Straalen. 2008. The unseen majority: soil 
microbes as drivers of plant diversity and productivity in terrestrial ecosystems. Ecology Letters 11:296-310.

Hole, D. G., A. J. Perkins, J. D. Wilson, I. H. Alexander, F. Grice, and A. D. Evans. 2005. Does organic farming benefit biodiversity? Biological Conservation 122:113-130.

Holzschuh, A., I. Steffan-Dewenter, D. Kleijn, and T. Tscharntke. 2007. Diversity of flowervisiting bees in cereal fields: effects of farming system, landscape composition and regional context. Journal of Applied Ecology 44:41-49.

Hooper, D. U., F. S. Chapin, J. J. Ewel, A. Hector, P. Inchausti, S. Lavorel, J. H. Lawton, D. M. Lodge, M. Loreau, S. Naeem, B. Schmid, H. Setala, A. J. Symstad, J. Vandermeer, and D. A. Wardle. 2005. Effects of biodiversity on ecosystem functioning: A consensus of current knowledge. Ecological Monographs 75:3-35.

Jenkins, D. G., C. R. Brescacin, C. V. Duxbury, J. A. Elliott, J. A. Evans, K. R. Grablow, M. Hillegass, B. N. LyonO, G. A. Metzger, M. L. Olandese, D. Pepe, G. A. Silvers, H. N. Suresch, T. N. Thompson, C. M. Trexler, G. E. Williams, N. C. Williams, and S. E. Williams. 2007. Does size matter for dispersal distance? Global Ecology and Biogeography 16:415-425.

Jouquet, P., J. Dauber, J. Lagerlof, P. Lavelle, and M. Lepage. 2006. Soil Invertebrates as Ecosystem Engineers: Intended and Accidental Effects on Soil and Feedback Loops. Applied Soil Ecology 32:153-164.

Leibold, M. A., M. Holyoak, N. Mouquet, P. Amarasekare, J. M. Chase, M. F. Hoopes, R. D. Holt, J. B. Shurin, R. Law, D. Tilman, M. Loreau, and A. Gonzalez. 2004. The metacommunity concept: a framework for multi-scale community ecology. Ecology Letters 7:601-613.

Loreau, M., N. Mouquet, and A. Gonzalez. 2003. Biodiversity as spatial insurance in heterogeneous landscapes. Proceedings of the National Academy of Science of the United States of America 100:12765-12770. 
Loreau, M., S. Naeem, P. Inchausti, J. Bengtsson, J. P. Grime, A. Hector, D. U. Hooper, M. A. Huston, D. Raffaelli, B. Schmid, D. Tilman, and D. A. Wardle. 2001. Ecology Biodiversity and ecosystem functioning: Current knowledge and future challenges. Science 294:804-808.

Mader, P., A. Fliessbach, D. Dubois, L. Gunst, P. Fried, and U. Niggli. 2002. Soil fertility and biodiversity in organic farming. Science 296:1694-1697.

Martiny, J. B. H., B. J. M. Bohannan, J. H. Brown, R. K. Colwell, J. A. Fuhrman, J. L. Green, M. C. Horner-Devine, M. Kane, J. A. Krumins, C. R. Kuske, P. J. Morin, S. Naeem, L. Ovreas, A. L. Reysenbach, V. H. Smith, and J. T. Staley. 2006. Microbial biogeography: putting microorganisms on the map. Nature Reviews Microbiology 4:102-112.

Matson, P. A., W. J. Parton, A. G. Power, and M. J. Swift. 1997. Agricultural intensification and ecosystem properties. Science 277:504-509.

Ostman, O., B. Ekbom, J. Bengtsson, and A. C. Weibull. 2001. Landscape complexity and farming practice influence the condition of polyphagous carabid beetles. Ecological Applications 11:480-488.

Purtauf, T., I. Roschewitz, J. Dauber, C. Thies, T. Tscharntke, and V. Wolters. 2005. Landscape Context of Organic and Conventional Farms: Influences on Carabid Beetle Diversity. Agriculture Ecosystems \& Environment 108:165-174.

Robinson, R. A., and W. J. Sutherland. 2002. Post-war changes in arable farming and biodiversity in Great Britain. Journal of Applied Ecology 39:157-176.

Roschewitz, I., D. Gabriel, T. Tscharntke, and C. Thies. 2005. The effects of landscape complexity on arable weed species diversity in organic and conventional farming. Journal of Applied Ecology 42:873-882.

Rundlof, M., H. Nilsson, and H. G. Smith. 2008. Interacting effects of farming practice and landscape context on bumblebees. Biological Conservation 141:417-426. 
Rundlof, M., and H. G. Smith. 2006. The effect of organic farming on butterfly diversity depends on landscape context. Journal of Applied Ecology 43:1121-1127.

Rusek, J. 1998. Biodiversity of Collembola and their functional role in the ecosystem. Biodiversity and Conservation 7:1207-1219.

Scheu, S., N. Schlitt, A. V. Tiunov, J. E. Newington, and T. H. Jones. 2002. Effects of the Presence and Community Composition of Earthworms on Microbial Community Functioning. Oecologia 133:254-260.

Schmidt, M. H., I. Roschewitz, C. Thies, and T. Tscharntke. 2005. Differential effects of landscape and management on diversity and density of ground-dwelling farmland spiders. Journal of Applied Ecology 42:281-287.

Schmidt, M. H., C. Thies, W. Nentwig, and T. Tscharntke. 2008. Contrasting responses of arable spiders to the landscape matrix at different spatial scales. Journal of Biogeography 35:157-166.

Schweiger, O., J. P. Maelfait, W. Van Wingerden, F. Hendrickx, R. Billeter, M. Speelmans, I. Augenstein, B. Aukema, S. Aviron, D. Bailey, R. Bukacek, F. Burel, T. Diekotter, J. Dirksen, M. Frenzel, F. Herzog, J. Liira, M. Roubalova, and R. Bugter. 2005. Quantifying the impact of environmental factors on arthropod communities in agricultural landscapes across organizational levels and spatial scales. Journal of Applied Ecology 42:1129-1139.

Stoate, C., N. D. Boatman, R. J. Borralho, C. R. Carvalho, G. R. de Snoo, and P. Eden. 2001. Ecological impacts of arable intensification in Europe. Journal of Environmental Management 63:337-365.

Strickland, M. S., C. Lauber, N. Fierer, and M. A. Bradford. 2009. Testing the functional significance of microbial community composition. Ecology 90:441-451.

Swift, M., A. Izac, and M. van Noordwijk. 2004. Biodiversity and ecosystem services in 
agricultural landscapes - are we asking the right questions? Agriculture ecosystems \& Envirnonment 104:113-134.

Tscharntke, T., A. M. Klein, A. Kruess, I. Steffan-Dewenter, and C. Thies. 2005. Landscape perspectives on agricultural intensification and biodiversity - ecosystem service management. Ecology Letters 8:857-874.

Tylianakis, J. M., A. M. Klein, T. Lozada, and T. Tscharntke. 2006. Spatial scale of observation affects alpha, beta and gamma diversity of cavity-nesting bees and wasps across a tropical land-use gradient. Journal of Biogeography 33:1295-1304.

Weiher, E., and A. Howe. 2003. Scale-dependence of environmental effects on species richness in oak savannas. Journal of Vegetation Science 14:917-920.

Wilsey, B. J., and C. Potvin. 2000. Biodiversity and ecosystem functioning: Importance of species evenness in an old field. Ecology 81:887-892.

Wright, J. P., S. Naeem, A. Hector, C. Lehman, P. B. Reich, B. Schmid, and D. Tilman. 2006. Conventional functional classification schemes underestimate the relationship with ecosystem functioning. Ecology Letters 9:111-120. 


\section{Chapter 2}

\section{AGRICULTURAL INTENSIFICATION AND BIODIVERSITY PARTITIONING ACROSS EUROPEAN LANDSCAPES COMPARING PLANTS, CARABIDS BEETLES AND BIRDS}

A. Flohre, C. Fischer, T. Aavik, J. Bengtsson, F. Berendse, R. Bommarco, P. Ceryngier, L.

W. Clement, C. Dennis, S. Eggers, M. Emmerson, F. Geiger, I. Guerrero, V. Hawro, P. Inchausti, J. Liira, M. B. Morales, J. J. Oñate, T. Pärt, W. W. Weisser, C. Winqvist, C. Thies,

T. Tscharntke 


\begin{abstract}
Effects of agricultural intensification (AI) on biodiversity are often assessed on the plot scale, although processes determining diversity operate also on larger spatial scales. Here, we analysed the diversity of vascular plants, carabid beetles and birds in agricultural landscapes in cereal crop fields at the field $(n=1350)$, farm $(n=270)$, and European region $(n=9)$ scale. We partitioned diversity into its additive components $\alpha, \beta$, and $\gamma$, and assessed the relative contribution of $\beta$-diversity to total species richness at each spatial scale. AI was determined using pesticide and fertilizer inputs as well as tillage operations and categorized into low, medium and high levels. As AI was not significantly related to landscape complexity, we could disentangle potential AI effects on local vs. landscape community homogenization. AI negatively affected the species richness of plants and birds, but not carabid beetles, at all spatial scales. Hence, local AI was closely correlated to $\beta$-diversity on larger scales up to the farm and region level, and thereby an indicator of farm and region wide biodiversity losses. $\beta$ diversity at the scale of farms (12.83 - 20.52\%) and regions $(68.34 \%-80.18 \%)$ accounted for the major part of the total species richness for all three taxa, indicating great dissimilarity in environmental conditions on larger spatial scales. For plants, relative importance of $\alpha$ diversity decreased with $\mathrm{AI}$, while relative importance of $\beta$-diversity on the farm scale increased with AI for carabids and birds. Hence, and in contrast to our expectations, AI does not necessarily homogenize local communities, presumably due to the heterogeneity of farming practices. In conclusion, a more detailed understanding of AI effects on diversity patterns of various taxa and at multiple spatial scales would contribute to more efficient agrienvironmental schemes in agroecosystems.
\end{abstract}

Key words: beta diversity, landscape ecology, community homogenization, biodiversity patterns 


\section{INTRODUCTION}

In the last decades global croplands, plantations and pastures have expanded significantly (Foley et al. 2005). This has led to dramatic changes in the spatial structure of agricultural landscapes in Western Europe. Formerly structurally diverse landscapes have often been converted to simple landscapes mainly consisting of intensively managed agricultural units ( Robinson and Sutherland 2002, Benton et al. 2003). Such increases in management intensity featured by higher pesticide and fertilizer inputs, tillage operations and livestock densities were accompanied by a profound loss of biodiversity (Matson et al. 1997, Stoate et al. 2001, Bengtsson et al. 2005, Foley et al. 2005). While effects of agricultural intensification (AI) have been a major topic in ecological research in the last decade, they have mainly been studied at the plot scale, although processes determining diversity operate at different spatial scales (Crawley and Harral 2001, Collins et al. 2002, Weiher and Howe 2003, Aavik and Liira 2010) and assessing diversity merely at one scale can be misleading (Tylianakis et al. 2006). For example, AI could lead to a homogenization of communities on e.g. the field scale, which could have profound effects on the species turnover between fields and hence to species richness on larger scales.

A useful tool to evaluate diversity at different spatial scales is the additive partitioning approach (Lande 1996, Veech et al. 2002, Crist et al. 2003, Legendre et al. 2005, Clough et al. 2007): The total diversity of a sampling unit $(\gamma)$ can be separated into different components: the $\alpha$-diversity, which is the average diversity on a plot scale and the $\beta$-diversity, which is the between-plot diversity. Thus $\beta$-diversity is a measure of variation in species composition between plots. $\beta$-diversity between plots and regions has been shown to account for up to $80 \%$ of the total species richness of arthropods (Tylianakis et al. 2006, Clough et al. 2007) or plants (Wagner et al. 2000, Gabriel et al. 2006), stressing the importance of $\beta$-diversity for total species richness. A more thorough understanding of the spatial organization of farmland diversity could give important insights into associated ecosystem processes and humanrelated drivers of species loss at different scales.

From an applied point of view, a more thorough understanding may be useful for selecting the appropriate scale for conservation efforts (e.g. agri-environmental schemes; Gering et al. 2003, Chandy et al. 2006), or for the identification of flexible conservation strategies (Gabriel et al. 2006, Diekotter et al. 2008) for different taxa.

Here, we applied diversity partitioning to a data set from a biodiversity survey conducted in cereal crop fields across nine regions in Europe. We analysed the effects of AI 
on species richness of plants, carabid beetles and birds in agricultural landscapes and hypothesized:

(i) AI has a negative effect on species richness of all taxa, with $\beta$-diversity making the major contribution to total diversity,

(ii) The three species groups respond differentially to AI on different spatial scales,

(iii) AI homogenizes communities across fields and these homogenization negatively affects species turnover between fields and regions.

(iv) Local AI is not only related to local biodiversity losses, but also to losses at larger spatial scales.

\section{METHODS}

\section{Study area and design}

The study was conducted in nine European regions covering a North-South gradient from Sweden and Estonia to Spain and a West-East gradient from Ireland to Poland (Estonia, France, East and West Germany separately, Ireland, Netherlands, Poland, Spain and Sweden, fig 1) in the context of the AGRIPOPES project (www.agripopes.net). In each region we selected 30 farms differing in the level of agricultural intensification (AI). Farms were situated in a $50 * 50 \mathrm{~km}^{2}$ region to standardize spatial scales and account for larger edaphic or topographic gradients. Each farm comprised ideally five cereal crop fields (see Geiger et al. 2010) for sampling of vascular plants and carabids and a $500 * 500 \mathrm{~m}^{2}$ square for sampling of breeding birds centred on the largest field of each farm. When one farm could not provide five fields, five sampling points with maximum distance to each other were chosen. Each sampling point consisted of three vegetation plots with a distance of five meters between each other and two pitfall traps placed in the middle of the outer vegetation plots. Plots were situated parallel to the field boundary with ten meters distance between field margin and sampling point. 


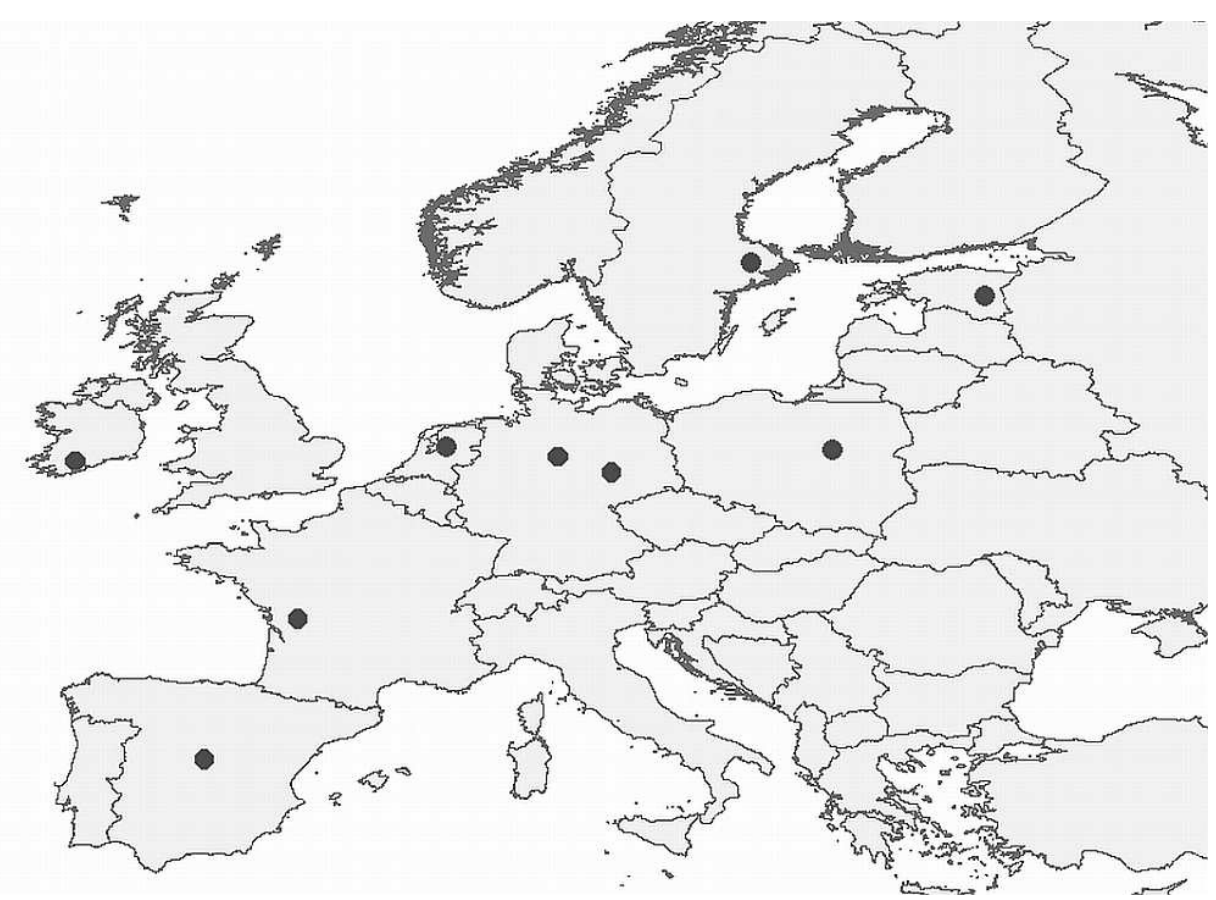

Fig 1: Map of the study areas. The locations of the study areas are indicated by black dots: Sweden, Estonia, Ireland, Netherlands, Germany (Göttingen), Germany (Jena), Poland, France and Spain (from Geiger et al. 2010).

\section{Sampling of organisms}

At the flowering stage of winter wheat the number of vascular plant species was counted in the vegetation plots (each $2 * 2 \mathrm{~m}^{2}$, three plots per field).

The number of carabid species was counted using two pitfall traps per plot (diameter $9 \mathrm{~cm}$ ), opened for two one-week periods (one week after spike appearance and at the milk ripening stage of winter wheat, respectively). The trapping fluid was $50 \%$ ethylene glycol. Carabids were stored in $70 \%$ ethanol and identified up to species level. We identified all the species caught in one trap, randomly selected from each pair of traps.

We used a simplified version of the British Trust for Ornithology's (BTO) Common Bird Census (Bibby et al. 1992) for bird species recording. All bird species were mapped in a 500 * $500 \mathrm{~m}^{2}$ survey plot on each farm centred on one focal field. Mapping included three early morning visits between April and June. Windy, cloudy or rainy weather was avoided. Birds that merely flew over the area without showing any behaviour that indicates breeding or foraging/hunting activity were excluded. Breeding bird territories were determined using the three survey rounds (details see supplementary material and supplementary Table 1). In some cases not only the focal field but also parts of the surrounding landscape were sampled. Our bird surveys thus were not restricted to arable bird species and include species from seminatural habitats next to the focal fields within the $500 * 500 \mathrm{~m}$ square. 
Agricultural intensification index

Agricultural intensification (AI) was measured using a standardized questionnaire on pesticide and fertilizer (mineral and organic) applications, tillage operations and mechanical weed control.

All of these indicators are known to have the potential to severely influence communities. Effects of fertilization on species richness and community composition of plants are well studied (Pysek and Leps 1991, Gough et al. 2000, Reich 2009). Likewise the effects of pesticides on plant, carabid and bird communities are well studied (Newton 2004, Geiger et al. 2010). Ploughing is assumed to affect plant (Dorado and Lopez-Fando 2006, Gruber and Claupein 2009), carabid (Thorbek and Bilde 2004) and bird (Newton 2004) communities. Although mechanical weed control is more frequently used in organic farming, the effects of mechanical weed control on plant and arthropod communities can be severe (van Elsen 2000, Hatcher and Melander 2003, Thorbek and Bilde 2004) and were therefore included into the AI index. Based on this information, we calculated an AI index for each farm. Three agricultural practices, namely pesticide input (number of applications), fertilizer input (amount of fertilizer per hectare applied) and the number of tillage operations and mechanical weeding were normalized, averaged and added following Herzog et al. (2006),

$$
A I=\frac{\sum_{i=1}^{n}\left(y_{i}-y_{i \min }\right) /\left(y_{i \max }-y_{i \min }\right)}{n} * 100
$$

where $\mathrm{AI}$ is the agricultural intensification index, $\mathrm{y}_{\mathrm{i}}$ the observed value, $\mathrm{y}_{\min }$ the minimum observed value in all regions, $\mathrm{y}_{\max }$ the maximum observed value in all regions, $\mathrm{n}$ the number of individual indicators and $i$ the identifier for the three indicators.

Based on this AI index each farm within a local 50x50km region was assigned to one level of agricultural intensification (low, medium and high). Within each region, farms were classified into three groups into ten farms of each AI level to avoid spatial autocorrelation of the AI levels over the whole study area (i.e. all regions; for mean AI index values per level see table1). To test for the effects of overlapping AI index values between AI levels and regions we additionally analysed a reduced dataset with data only from regions with similar AI index values for the low, medium and high AI treatments, i.e. France, Ireland and Sweden were excluded, which yielded comparable results (supplementary material Tables S2, S3 and S4). Hence we used the whole dataset in the present analysis. 
Table 1: Mean AI index values for low, medium and high AI levels in each region and for all regions combined

\begin{tabular}{cccc}
\hline & \multicolumn{3}{c}{ mean AI index \pm standard errors } \\
\cline { 2 - 4 } Region & low & medium & high \\
\hline Estonia & $5.53 \pm 0.51$ & $15.03 \pm 1.46$ & $24.43 \pm 1.12$ \\
France & $13.54 \pm 0.73$ & $16.21 \pm 0.18$ & $18.04 \pm 0.33$ \\
Germany Göttingen & $3.07 \pm 0.73$ & $16.63 \pm 2.56$ & $32.11 \pm 2.28$ \\
Germany Jena & $13.63 \pm 1.72$ & $27.81 \pm 0.78$ & $36.42 \pm 1.96$ \\
Ireland & $29.74 \pm 1.21$ & $31.76 \pm 1.10$ & $33.06 \pm 0.97$ \\
Netherlands & $13.47 \pm 1.65$ & $22.39 \pm 0.70$ & $35.30 \pm 3.04$ \\
Poland & $14.98 \pm 1.22$ & $21.15 \pm 0.71$ & $30.71 \pm 1.95$ \\
Spain & $14.70 \pm 1.07$ & $20.87 \pm 0.56$ & $27.11 \pm 1.27$ \\
Sweden & $5.18 \pm 0.80$ & $13.20 \pm 0.49$ & $19.95 \pm 1.57$ \\
\hline Overall mean & $12.65 \pm 0.84$ & $20.56 \pm 0.65$ & $28.57 \pm 0.70$ \\
\hline
\end{tabular}

To ensure that our results are independent from landscape complexity and field size we tested for correlations between AI levels and landscape complexity and mean field size. AI levels were independent from landscape complexity (percentage non-crop area in a $500 \mathrm{~m}$ radius, Pearsons $r_{292}:-0.003$ n.s.) and mean field size (Pearsons $r_{1465}: 0.12$ n.s.).

\section{Additive partitioning of species diversity}

The total observed non-rarefied species richness $\gamma_{\text {obs }}$ for each AI level and community can be partitioned as:

$\gamma_{\mathrm{obs}}=\alpha+\beta_{\text {field }}+\beta_{\text {farm }}+\beta_{\text {region }}$

where $\alpha$ is the mean $\alpha$-diversity per field, $\beta_{\text {field }}$ is the between field $\beta$-diversity, $\beta_{\text {farm }}$ is the mean between farm $\beta$-diversity and $\beta_{\text {region }}$ is the mean between region $\beta$-diversity. Because birds were sampled on the farm level, bird data could only be partitioned into $\gamma_{\mathrm{obs}}=\alpha_{\mathrm{farm}}+$ $\beta_{\text {farm }}+\beta_{\text {region }}$.

These values can be obtained as follows:

$\alpha=\frac{1}{n} \sum_{\mathrm{ijk}} \alpha_{\mathrm{ijk}}$ 


$$
\begin{aligned}
& \beta_{\text {field }}=\frac{1}{n} \sum_{i j k}\left(\gamma_{j k}-\alpha_{i j k}\right) \\
& \beta_{\text {farm }}=\frac{1}{N} \sum_{j k}\left(\gamma_{k}-\gamma_{j k}\right) \\
& \beta_{\text {region }}=\frac{1}{M} \sum_{k}\left(\gamma_{o b s}-\gamma_{k}\right)
\end{aligned}
$$

where $\mathrm{n}$ is the total number of fields (450), $\mathrm{N}$ the total number of farms within regions (90), $\mathrm{M}$ the total number of regions (9), $\mathrm{i}$ the identifier for field within farm, $\mathrm{j}$ the identifier for farm within region (90) and $\mathrm{k}$ the identifier for each region (9).

We also calculated the relative $\alpha$ - and $\beta$-diversities, i.e. percentaged contribution of $\alpha$ - and $\beta$ diversities to $\gamma_{\text {obs }}$.

\section{Statistical models}

Linear mixed effects models were used to test the effects of agricultural intensification on the $\alpha-, \beta$ - and $\gamma$-diversity of carabids, plants and birds species richness. AI was included as a factor with three levels, low, medium and high. $\alpha$ - and $\beta$-diversities were tested separately at field, farm and regional scale, respectively. i.e. one model for the effect of AI on the $\alpha$ diversity on the field scale, one model for the effect of AI on the $\beta$-diversity on the field scale, one model for the effect of AI on the $\beta$-diversity on the farm scale, etc. In total, we analysed 450 observations per AI level at the field scale, 90 calculations of $\beta$-diversities per AI level at the farm scale, and 9 calculations of $\beta$-diversities per AI level at the regional scale. The total number of replications (n) for the models was 1350 at the field level, 270 at the farm level and 27 on the region level. Because these observations were not independent from each other, fields were nested within farms and farms were nested within regions and included as random factors into the models. We analysed the effects of AI on the relative contribution using linear mixed effect models with the same nesting structure. Model assumptions were checked using diagnosis plots and dependent variables were either log- or square-root-transformed and/or variance functions were used (Pinheiro and Bates 2000) to account for non-normal distribution and heteroscedasticity when necessary. The significance of AI in each model was determined by using conditional $F$ tests, where the null model was tested against a model with AI.

We applied paired t-tests on the whole dataset of each taxon, i.e. across all AI levels, to test for taxon specific differences of percentaged contribution to total species richness. On each 
scale one t-test per taxon combination was done. Posthoc Tukey-HSD tests were applied to separate means. All analyses were performed using R 2.8.1 (R Development Core Team 2008) and the packages nlme and multcomp.

\section{RESULTS}

\section{Effects of AI level on $\alpha$-, $\beta$ - and $\gamma$-diversity of plants, carabids and birds}

In total, we recorded 423 vascular plant species, 219 carabid beetle species and 121 bird species.

Comparisons of the $\alpha$ - and $\beta$-diversities between low, medium and high agricultural intensification (AI) revealed that the effects of AI on species richness were taxon specific. High AI significantly decreased $\alpha$ - and $\beta$-diversities of plants at all scales, while $\beta$-diversities of carabids were only decreased at the region scale and bird $\beta$-diversities were decreased at the farm and region scale (Table 2 and Figure 2).
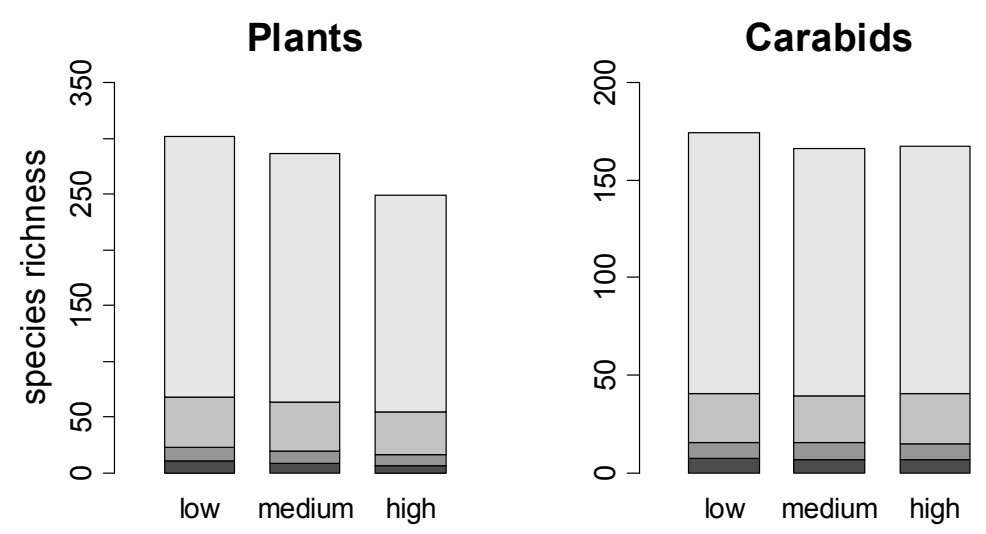

\section{Birds}

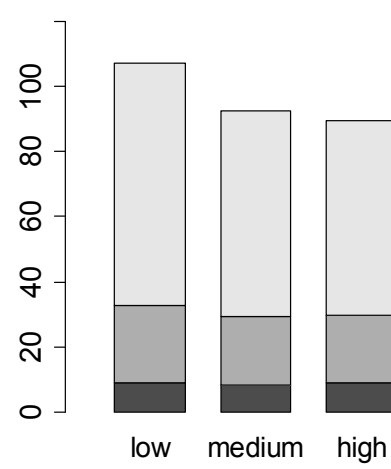

$\beta$-region $\beta$-farm $\beta$-field mean $\alpha$

Figure 2: Effect of AI level (low, medium and high) on species richness of plants, carabids and birds, separating $\alpha$-diversity on the field and $\beta$-diversity between fields, farms and regions. 
Table 2: Effect of AI level (low, medium and high) on the $\alpha$ - and $\beta$-diversities of the three taxa (absolute values, mean number of species). $F$ - and p-values and denominator degrees of freedom (d.f.) of conditional $F$ tests performed on linear mixed effect models are given. Significant differences between species richness estimates are marked by different alphabetic characters. n.s. not significant, $* \mathrm{P}<0.05 ; * * \mathrm{P}<0.01 ; * * * \mathrm{P}<0.001$.

\begin{tabular}{lllllll}
\hline & & & & \multicolumn{2}{c}{ Species richness estimates } \\
\cline { 5 - 7 } Taxon & Scale & d.f. & $F$-Value & Low & Medium & High \\
\hline Plants & $\alpha$ & 253 & $14.61^{* * *}$ & $8.89_{\mathrm{b}}$ & $6.68_{\mathrm{a}}$ & $5.32_{\mathrm{a}}$ \\
Plants & $\beta_{\text {field }}$ & 253 & $5.08^{* *}$ & $9.80_{\mathrm{b}}$ & $8.89_{\mathrm{ab}}$ & $7.17_{\mathrm{a}}$ \\
Plants & $\beta_{\text {farm }}$ & 253 & $13.27^{* * *}$ & $44.04_{\mathrm{a}}$ & $44.39_{\mathrm{a}}$ & $38.30_{\mathrm{b}}$ \\
Plants & $\beta_{\text {region }}$ & 16 & $23.63^{* * *}$ & $232.92_{\mathrm{a}}$ & $220.84_{\mathrm{a}}$ & $195.74_{\mathrm{b}}$ \\
Carabids & $\alpha$ & 253 & 2.51 n.s. & 6.39 & 6.30 & 5.80 \\
Carabids & $\beta_{\text {field }}$ & 253 & 0.81 n.s. & 7.43 & 7.91 & 7.74 \\
Carabids & $\beta_{\text {farm }}$ & 253 & 2.29 n.s. & 24.44 & 23.79 & 25.36 \\
Carabids & $\beta_{\text {region }}$ & 16 & $5.85^{* *}$ & $133.8_{\mathrm{a}}$ & $127.4_{\mathrm{b}}$ & $126.2_{\mathrm{b}}$ \\
Birds & $\alpha$ & 219 & 2.13 n.s. & 8.41 & 7.65 & 7.49 \\
Birds & $\beta_{\text {farm }}$ & 219 & $4.88^{* *}$ & $22.37_{\mathrm{a}}$ & $19.94_{\mathrm{ab}}$ & $19.20_{\mathrm{b}}$ \\
Birds & $\beta_{\text {region }}$ & 14 & $7.98^{* *}$ & $72.88_{\mathrm{a}}$ & $64_{\mathrm{b}}$ & $59.63_{\mathrm{b}}$ \\
\hline
\end{tabular}

Effects of AI level on the relative contribution of $\alpha$-, $\beta$ - and $\gamma$-diversity to the total species richness of plants, carabids and birds

Shifts in relative contribution of $\alpha$ - and $\beta$-diversity to the total species richness within AI levels, estimated as percentage of total diversity, were taxon specific (table 3). Plants had a significantly larger relative contribution of $\alpha$-diversity at the low AI level, while carabids had higher relative $\beta_{\text {field }}$ diversity at the high and medium compared to the low AI level. Birds showed higher relative $\alpha$-diversity at medium and low compared to high AI level. 
Table 3: Effect of AI-level on the relative contribution (\% of total) of $\alpha$ - and $\beta$-diversities to the $\gamma$-diversity of each taxa within each AI level. $F$ - and p-values and denominator degrees of freedom (d.f.) of conditional $F$ tests performed on linear mixed effect models are given. Significant differences between $\%$ of total species richness estimates are marked by different alphabetic characters. n.s. not significant, $* \mathrm{P}<0.05 ; * * \mathrm{P}<0.01 ; * * * \mathrm{P}<0.001$.

\begin{tabular}{ccccccc}
\hline & & & & \multicolumn{3}{c}{$\%$ of total species richness } \\
Taxon & Scale & d.f. & $F$-Value & \multicolumn{3}{c}{ estimates } \\
\cline { 5 - 7 } & & & & Low & Medium & High \\
\hline Plants & $\alpha$ & 253 & $6.64^{* *}$ & 2.99 a & $2.38_{\mathrm{b}}$ & $2.18_{\mathrm{b}}$ \\
Plants & $\beta_{\text {field }}$ & 253 & 0.82 n.s. & 3.45 & 3.29 & 3.08 \\
Plants & $\beta_{\text {farm }}$ & 253 & 0.13 n.s. & 13.90 & 14.05 & 14.19 \\
Plants & $\beta_{\text {region }}$ & 16 & 0.15 n.s. & 77.63 & 77.66 & 78.58 \\
Carabids & $\alpha$ & 253 & 1.64 n.s. & 3.69 & 3.79 & 3.45 \\
Carabids & $\beta_{\text {field }}$ & 253 & 2.39 n.s. & 4.29 & 4.75 & 4.65 \\
Carabids & $\beta_{\text {farm }}$ & 253 & $3.68 *$ & $14.21_{\mathrm{ab}}$ & $14.40_{\mathrm{a}}$ & $15.34_{\mathrm{b}}$ \\
Carabids & $\beta_{\text {region }}$ & 16 & 0.48 n.s. & 76.95 & 76.31 & 75.58 \\
Birds & $\alpha$ & 219 & 0.73 n.s. & 8.63 & 8.77 & 9.25 \\
Birds & $\beta_{\text {farm }}$ & 219 & $8.57^{* * *}$ & $21.17_{\mathrm{a}}$ & $21.77 \mathrm{a}$ & $23.79_{\mathrm{b}}$ \\
Birds & $\beta_{\text {region }}$ & 14 & 0.00 n.s. & 68.75 & 68.82 & 68.53 \\
\hline
\end{tabular}

Effects of taxon on the relative contribution of $\alpha$ - and $\beta$-diversity to total species richness A comparison of the mean relative contribution to total diversity regardless of AI level on each scale between plants, carabids and birds (Table 4) showed that the more mobile taxa in this study had on average significantly higher diversity. On the field scale carabids showed higher $\alpha$ - and $\beta$-diversity than plants. On the landscape scale no differences between plants and carabids were apparent, while birds had higher $\beta$-diversity than carabids and plants. On the region scale plants and carabids also did not differ, but both were higher than bird diversity. 
Table 4: Results of paired t-tests comparing the relative contribution of each scale to taxon specific total species richness between the different taxa; $* \mathrm{P}<0.05 ; * * \mathrm{P}<0.01$; *** $\mathrm{P}<0.001 ; \mathrm{P}=$ plants, $\mathrm{C}=$ carabids, $\mathrm{B}=$ birds

\begin{tabular}{clccc}
\hline Scale & \multicolumn{1}{c}{ Taxon } & t-value & d.f. & $\begin{array}{c}\text { Direction of } \\
\text { effect }\end{array}$ \\
\hline$\alpha$ & Plants - Carabids & $-14.07^{* * *}$ & 1315 & $\mathrm{P}<\mathrm{C}$ \\
$\beta_{\text {field }}$ & Plants - Carabids & $-10.95^{* * *}$ & 1315 & $\mathrm{P}<\mathrm{C}$ \\
$\beta_{\text {farm }}$ & Plants - Carabids & 1.24 n.s. & 263 & $\mathrm{P}=\mathrm{C}$ \\
$\beta_{\text {farm }}$ & Plants - Birds & $-12.13^{* * *}$ & 228 & $\mathrm{~B}>\mathrm{P}$ \\
$\beta_{\text {farm }}$ & Carabids - Birds & $-11.22^{* * *}$ & 228 & $\mathrm{~B}>\mathrm{C}$ \\
$\beta_{\text {region }}$ & Plants - Carabids & 0.97 n.s. & 26 & $\mathrm{P}=\mathrm{C}$ \\
$\beta_{\text {region }}$ & Plants - Birds & $3.68^{* * *}$ & 23 & $\mathrm{~B}<\mathrm{P}$ \\
$\beta_{\text {region }}$ & Carabids - Birds & $3.10^{* * *}$ & 23 & $\mathrm{~B}<\mathrm{C}$ \\
\hline
\end{tabular}

\section{DISCUSSION}

The analysis of diversity patterns of plants, carabid beetles and birds in agricultural landscapes across Europe showed that $\beta$-diversity between farms and regions contributed most to total diversity. Agricultural intensification (AI) was negatively correlated with species richness of plants and birds, whereas carabid beetles showed no such relationships, thus confirming our hypotheses that AI has a negative effect on species richness depending on taxon. AI, although based on local practices, was closely related to the $\beta$-diversity on larger scales up to the region scale, with the detrimental effects of AI still recognizable on higher scales. Hence AI at local scales appeared to be an indicator of farm and region wide loss of diversity.

\section{Effects of AI on species richness across different taxa}

The great role of $\beta$-diversity contribution to overall biodiversity at the regional scale has been shown by several studies (Wagner et al. 2000, Roschewitz et al. 2005, Gabriel et al. 2006, Clough et al. 2007, Hendrickx et al. 2007) and stress the huge importance of environmental heterogeneity at larger scales.

In this study, plant species richness was significantly reduced under intensive management. This detrimental effect of high input farming was consistent over all scales, indicating species 
poorer plant communities under high AI. This is supported by the literature, showing positive effects of reduced input farming, i.e. reduced pesticide and/or reduced fertilizer input, on plant species richness (Stoate et al. 2001, Bengtsson et al. 2005, Gabriel et al. 2006, Liira et al. 2008, Kleijn et al. 2009).

In contrast, AI had no effect on the species richness of carabids on the field and farm scale, although detrimental effects of soil management, for example ploughing, mechanical weed control or grass cutting on arthropods are well known (Holland and Reynolds 2003, Thorbek and Bilde 2004). However, pesticide use in crop edges usually does not seem to affect carabids species richness negatively (Frampton et al. 2007), although pesticides may change carabid abundance and community composition directly and indirectly (Shah et al. 2003, Navntoft et al. 2006, Geiger et al. 2010). Our results comply with studies showing no effect of AI on the species richness of carabids in cereal fields at the regional and local scale (Clough et al. 2007, Batary et al. 2008, but see Geiger et al. 2010). Only at the region scale a positive effect of lower AI on $\beta$-diversity existed, indicating more dissimilar and diverse carabid communities between regions under low AI management (something similar was found in (Schweiger et al. 2005, Hendrickx et al. 2009).

Bird species richness was enhanced under low AI. This could be due to improved food and nesting resource availability in low intensity management fields (Stephens et al. 2003), stressing the importance of physical heterogeneity on the field as an important determinant of bird diversity (Wilson et al. 2005). Especially granivorous birds could be affected through the loss of food and nesting resources through weed control at higher AI (Newton 2004).

\section{AI effects across different spatial scales}

If local AI determines local diversity of a specific set of species out of the species pool, AI would enhance the relative importance (i.e. percentage contribution of $\alpha$-diversity to $\gamma$ diversity) of $\alpha$-diversity, homogenizing community composition between sites due to increasingly similar environmental conditions (Tylianakis et al. 2005, Quintero et al. 2010). In our study AI on the field was not related to large-scale land-use changes, as AI was not significantly correlated with landscape complexity. Hence local effects of AI could be disentangling from effects such as landscape homogenization. In contrast to the expected enhancement of the relative importance of $\alpha$-diversity local AI decreased the relative $\alpha$ diversity of plants and increased the relative importance of $\beta_{\text {farm }}$-diversity of birds and carabids under high AI, indicating an increased species turnover. Hence AI does not 
necessarily homogenize local communities presumably due to heterogeneity of farming practices in intensified agriculture.

\section{Differences in spatial diversity patterns between plants, carabids and birds}

Species group identity had a significant effect on the spatial diversity patterns, indicated by a different partitioning of diversity components (relative $\alpha, \beta_{\text {field }}, \beta_{\text {farm }}$ and $\beta_{\text {region }}$ ). One could expect birds to have on average a higher mobility and possibly higher dispersal ability than carabids. Both taxa are surely more mobile than plants as sessile organisms. The more mobile taxa had on average less similar communities on the field and farm level than plants (table 4), i.e. $\alpha_{\text {field }}$ and $\beta_{\text {field }}$ represented a greater proportion of $\gamma$ diversity for carabids and $\alpha_{\text {farm, }} \beta_{\text {farm }}$ and $\beta_{\text {region }}$ represented a greater proportion of $\gamma$ diversity for birds in comparison to plants. One possible explanation are spillover effects from the adjacent non-crop habitats for more mobile taxa, which could lead to variance in the local species composition (Hendrickx et al. 2009), as supported by several studies stressing the importance of the surrounding landscape and field margins for the within field carabid community (Denys and Tscharntke 2002, Schweiger et al. 2005, Hendrickx et al. 2007, Batary et al. 2008, Smith et al. 2008). Likewise the importance of species rich field margins and semi-natural habitats for within field species richness has already been shown for many other arthropod taxa depending on body size (ability for mobility) (Schmidt et al. 2005, Schmidt and Tscharntke 2005, Schweiger et al. 2005, Holland et al. 2009) and farmland birds (Vickery et al. 2002). For plants, however, the picture could be a little different. The within field environmental conditions between farms are likely more similar than the environmental conditions in the surrounding landscapes around these fields. For plants as less mobile taxa, this could act as a homogenizing force, filtering out species with specific traits and life histories (Liira et al. 2008b). Plant species richness might be more strongly affected by local management than by landscape and field margin composition and structure (Gabriel et al. 2006, Aavik et al. 2008, Marshall 2009), although landscape can have a relevant effect, especially at high landscape complexity (Gabriel et al. 2005, Roschewitz et al. 2005, Aavik and Liira 2010). This is in line with results of a meta analysis from Attwood et al. (Attwood et al. 2008) which show that the loss of species richness of arthropods from native to agricultural systems is greater than that through AI within agricultural systems.

Birds had a higher relative $\beta$-diversity on the farm scale than plants and carabids, indicating relatively more dissimilar communities. Because bird species richness was measured in a 500 * $500 \mathrm{~m}$ square, sometimes not only the focal field but parts of the surrounding landscape 
were sampled too. However, AI and size of the focal field were not correlated in our study, hence disentangling AI and field size effects.

At the region scale, birds had a significantly lower relative $\beta$-diversity than plants and carabids, indicating a possible homogenizing effect of dispersal ability on species richness (Mouquet and Loreau 2003, Cadotte 2006). With increasing dispersal ability, species turnover between plots should decrease, caused by community homogenization between plots through dispersal over long distances.

\section{Conclusions and management implications}

Our study shows that $\beta$-diversity and accounted for the major part of the total diversity, an effect consistent over all nine European regions included in this study. AI decreased species richness of plants and birds on all scales, i.e. local AI did not only negatively affect the local diversity on the field, but was also related to the reduced species turnover between fields, farms and regions. In contrast, carabid beetle species richness was not affected by AI, possibly due to a relatively high tolerance to pesticides and a high impact of immigration from surrounding field margins and semi-natural habitats.

AI did not cause the hypothesized higher relative contribution of $\alpha$ - than $\beta$-diversity to total diversity, which would have indicated a homogenizing effect of AI. Relative contributions of $\beta$-diversity to total diversity across all scales were taxon specific, highlighting the need to consider traits such as species mobility when planning agri-environmental schemes. Therefore, agri-environmental schemes need (1) to expand the view from the local field and farm to the landscape and region level to appropriately predict the effectiveness of agrienvironmental schemes, shown by the huge contribution of beta diversity of large scales, and (2) to consider taxon specific responses to conservation efforts.

\section{ACKNOWLEDGEMENTS}

We thank the people who did the bird surveys and Christoph Scherber for statistical advise. We also thank the European Science Foundation and the connected eight national science foundations for funding the presented study through the Eurodiversity AGRIPOPES (http://www.agripopes.net) programme and the biolog programme (BIOPLEX http://www.uni-giessen.de/bioplex) of the German Federal Ministry of Education and Science (BMBF). 


\section{REFERENCES}

Aavik, T and J. Liira. 2010. Quantifying the effect of organic farming, field boundary type and landscape structure on the vegetation of field boundaries. Agriculture, Ecosystems \& Environment 135: 178-186.

Aavik,T., I. Augenstein, D. Bailey, F. Herzog, M. Zobel and J. Liira. 2008. What is the role of local landscape structure in the vegetation composition of field boundaries? Applied Vegetation Science 11: 375-386.

Attwood, S. J., M. Maron, A. P. N. House, and C. Zammit. 2008. Do arthropod assemblages display globally consistent responses to intensified agricultural land use and management? Global Ecology and Biogeography17:585-599.

Batary, P., A. Kovacs, and A. Baldi. 2008. Management effects on carabid beetles and spiders in Central Hungarian grasslands and cereal fields. Community Ecology 9:247-254.

Bengtsson, J., J. Ahnstrom, and A. C. Weibull. 2005. The effects of organic agriculture on biodiversity and abundance: a meta-analysis. Journal of Applied Ecology 42:261-269.

Benton, T. G., J. A. Vickery, and J. D. Wilson. 2003. Farmland biodiversity: is habitat heterogeneity the key? Trends in Ecology and Evolution 18:182-188.

Bibby, J. C., D. N. Burgress, and A. D. Hill. 1992. Bird Census Techniques. Academic Press, London.

Cadotte, M. W. 2006. Dispersal and species diversity: A meta-analysis. American Naturalist 167:913-924.

Chandy, S., D. J. Gibson, and P. A. Robertson. 2006. Additive partitioning of diversity across hierarchical spatial scales in a forested landscape. Journal of Applied Ecology 43:792801.

Clough, Y., A. Holzschuh, D. Gabriel, T. Purtauf, D. Kleijn, A. Kruess, I. Steffan-Dewenter, and T. Tscharntke. 2007. Alpha and beta diversity of arthropods and plants in 
organically and conventionally managed wheat fields. Journal of Applied Ecology 44:804-812.

Collins, S. L., S. M. Glenn, and J. M. Briggs. 2002. Effect of local and regional processes on plant species richness in tallgrass prairie. Oikos 99:571-579.

Crawley, M. J., and J. E. Harral. 2001. Scale dependence in plant biodiversity. Science 291:864-868.

Crist, T., J. Veech, J. Gering, and K. Summerville. 2003. Partitioning species diversity across landscapes and regions: A hierarchical analysis of alpha, beta, and gamma diversity. American Naturalist 162:734-743.

Denys, C., and T. Tscharntke. 2002. Plant-insect communities and predator-prey ratios in field margin strips, adjacent crop fields, and fallows. Oecologia 130:315-324.

Diekotter, T., R. Billeter, and T. O. Crist. 2008. Effects of landscape connectivity on the spatial distribution of insect diversity in agricultural mosaic landscapes. Basic and Applied Ecology 9:298-307.

Dorado, J., and C. Lopez-Fando. 2006. The effect of tillage system and use of a paraplow on weed flora in a semiarid soil from central Spain. Weed Research 46:424-431.

van Elsen, T. 2000. Species diversity as a task for organic agriculture in Europe. Agriculture Ecosystems \& Environment 77:101-109.

Foley, J. A., R. DeFries, G. P. Asner, C. Barford, G. Bonan, S. R. Carpenter, F. S. Chapin, M. T. Coe, G. C. Daily, H. K. Gibbs, J. H. Helkowski, T. Holloway, E. A. Howard, C. J. Kucharik, C. Monfreda, J. A. Patz, I. C. Prentice, N. Ramankutty, and P. K. Snyder. 2005. Global consequences of land use. Science 309:570-574.

Frampton, G. K., P. J. L. Gould, P. J. van den Brink, and E. Hendy. 2007. Type 'A' and 'B' recovery revisited: The role of field-edge habitats for Collembola and macroarthropod community recovery after insecticide treatment. Environmental Pollution 145:874- 
883.

Gabriel, D., I. Roschewitz, T. Tscharntke, and C. Thies. 2006. Beta diversity at different spatial scales: Plant communities in organic and conventional agriculture. Ecological Applications 16:2011-2021.

Geiger,F., J. Bengtsson, F. Berendse, W. W. Weisser, M. Emmerson, M. B. Morales, P. Ceryngier, J. Liira, T. Tscharntke, C. Winqvist, S. Eggers, R. Bommarco, T. Pärt, V. Bretagnolle, M. Plantegenest, L. W. Clement, C. Dennis, C. Palmer, J. J. Onate, I. Guerrero, V. Hawro, T. Aavik. C. Thies, A. Flohre, S. Hänke, C. Fischer, P. W. Goedhart and P. Inchausti. 2010. Persistent negative effects of pesticides on biodiversity and biological control potential on European farmland. Basic and Applied Ecology, doi:10.1016/j.baae.2009.12.001

Gering, J. C., T. O. Crist, and J. A. Veech. 2003. Additive partitioning of species diversity across multiple spatial scales: Implications for regional conservation of biodiversity. Conservation Biology 17:488-499.

Gough, L., C. W. Osenberg, K. L. Gross, and S. L. Collins. 2000. Fertilization effects on species density and primary productivity in herbaceous plant communities. Oikos 89:428-439.

Gruber, S., and W. Claupein. 2009. Effect of tillage intensity on weed infestation in organic farming. Soil and Tillage Research 105:104-111.

Hatcher, P. E., and B. Melander. 2003. Combining physical, cultural and biological methods: prospects for integrated non-chemical weed management strategies. Weed Research 43:303-322.

Hendrickx, F., J. P. Maelfait, K. Desender, S. Aviron, D. Bailey, T. Diekotter, L. Lens, J. Liira, O. Schweiger, M. Speelmans, V. Vandomme, and R. Bugter. 2009. Pervasive effects of dispersal limitation on within- and among-community species richness in agricultural landscapes. Global Ecology and Biogeography 18:607-616. 
Hendrickx, F., J. P. Maelfait, W. Van Wingerden, O. Schweiger, M. Speelmans, S. Aviron, I. Augenstein, R. Billeter, D. Bailey, R. Bukacek, F. Burel, T. Diekotter, J. Dirksen, F. Herzog, J. Liira, M. Roubalova, V. Vandomme, and R. Bugter. 2007. How landscape structure, land-use intensity and habitat diversity affect components of total arthropod diversity in agricultural landscapes. Journal of Applied Ecology 44:340-351.

Herzog, F., B. Steiner, D. Bailey, J. Baudry, R. Billeter, R. Bukacek, G. De Blust, R. De Cock, J. Dirksen, C. F. Dormann, R. De Filippi, E. Frossard, J. Liira, T. Schmidt, R. Stockli, C. Thenail, W. van Wingerden, and R. Bugter. 2006. Assessing the intensity of temperate European agriculture at the landscape scale. European Journal of Agronomy 24:165-181.

Holland, J. M., T. Birkett, and S. Southway. 2009. Contrasting the farm-scale spatio-temporal dynamics of boundary and field overwintering predatory beetles in arable crops. Biocontrol 54:19-33.

Holland, J. M., and C. J. M. Reynolds. 2003. The impact of soil cultivation on arthropod (Coleoptera and Araneae) emergence on arable land. Pedobiologia 47:181-191.

Hothorn, T, Bretz, F., and P. Westfall (2008). Simultaneous Inference in General Parametric Models. Biometrical Journal 50(3), 346--363.

Kleijn, D., F. Kohler, A. Baldi, P. Batary, E. D. Concepcion, Y. Clough, M. Diaz, D. Gabriel, A. Holzschuh, E. Knop, A. Kovacs, E. J. P. Marshall, T. Tscharntke, and J. Verhulst. 2009. On the relationship between farmland biodiversity and land-use intensity in Europe. Proceedings of the Royal Society of London B Biological Sciences 276:903909.

Lande, R. 1996. Statistics and partitioning of species diversity, and similarity among multiple communities. Oikos 76:5-13.

Legendre, P., D. Borcard, and P. R. Peres-Neto. 2005. Analyzing beta diversity: Partitioning the spatial variation of community composition data. Ecological Monographs 75:435450 . 
Liira, J., D. Bailey, R. Bugter, P. Arens, I. Augenstein, S. Aviron, J. Baudry, R. Bukacek, F. Burel, M. Cerny, G. De Blust, R. De Cock, T. Diekotter, H. Dietz, J. Dirksen, C. Dormann, W. Durka, M. Frenzel, R. Hamersky, F. Herzog, S. Klotz, B. Koolstra, A. Lausch, D. Le Coeur, J. P. Maelfait, P. Opdam, M. Roubalova, A. Schermann, N. Schermann, T. Schmidt, O. Schweiger, M. J. M. Smulders, M. Speelmans, P. Simova, J. Verboom, W. K. R. E. van Wingerden, M. Zobel, and P. J. Edwards. 2008. Indicators for biodiversity in agricultural landscapes: a pan-European study. Journal of Applied Ecology 45:141-150.

Liira,J.; T. Schmidt; T. Aavik, P. Arens; I. Augenstein; D. Bailey; R. Billeter; R. Bukacek; F. Burel, G. De Blust, R. De Cock, J. Dirksen, P.J. Edwards, R. Hamersky, F. Herzog, S. Klotz, I. Kühn, D. Le Coeur, P. Miklova, M. Roubalova, O. Schweiger, M.J.M. Smulders, W.K.R.E. van Wingerden, R. Bugter, M. Zobel. 2008b. Plant functional group composition and large-scale species richness in the agricultural landscapes of Europe. Journal of Vegetation Science 19: 3-14.

Marshall, E. J. P. 2009. The impact of landscape structure and sown grass margin strips on weed assemblages in arable crops and their boundaries. Weed Research 49:107-115.

Matson, P. A., W. J. Parton, A. G. Power, and M. J. Swift. 1997. Agricultural intensification and ecosystem properties. Science 277:504-509.

Mouquet, N., and M. Loreau. 2003. Community patterns in source-sink metacommunities. American Naturalist 162:544-557.

Navntoft, S., P. Esbjerg, and W. Riedel. 2006. Effects of reduced pesticide dosages on carabids (Coleoptera : Carabidae) in winter wheat. Agricultural and Forest Entomolgy $8: 57-62$

Newton, I. 2004. The recent declines of farmland bird populations in Britain: an appraisal of causal factors and conservation actions. Ibis 146:579-600.

Pinheiro, J. C., and D. M. Bates. 2000. Mixed-effects Models in S and S-PLUS, 1. edition. Springer, New York. 
Pinheiro, J.C., Bates, D. M., DebRoy, S., Sarkar, D., and the R Core team (2009). nlme: Linear and Nonlinear Mixed Effects Models. R package version 3.1-93.

Pysek, P., and J. Leps. 1991. Response of a Weed Community to Nitrogen-Fertilization - a Multivariate-Analysis. Journal of Vegetation Science 2:237-244.

Quintero, C., C. L. Morales, and M. A. Aizen. 2010. Effects of anthropogenic habitat disturbance on local pollinator diversity and species turnover across a precipitation gradient. Biodiversity and Conservation 19:257-274.

R Development Core Team (2009) R: A Language and Environment for Statistical Computing. In. R Foundation for Statistical Computing, Vienna, Austria

Reich, P. B. 2009. Elevated CO2 Reduces Losses of Plant Diversity Caused by Nitrogen Deposition. Science 326:1399-1402.

Robinson, R. A., and W. J. Sutherland. 2002. Post-war changes in arable farming and biodiversity in Great Britain. Journal of Applied Ecology 39:157-176.

Roschewitz, I., D. Gabriel, T. Tscharntke, and C. Thies. 2005. The effects of landscape complexity on arable weed species diversity in organic and conventional farming. Journal of Applied Ecology 42:873-882.

Schmidt, M. H., I. Roschewitz, C. Thies, and T. Tscharntke. 2005. Differential effects of landscape and management on diversity and density of ground-dwelling farmland spiders. Journal of Applied Ecology 42:281-287.

Schmidt, M. H., and T. Tscharntke. 2005. The role of perennial habitats for Central European farmland spiders. Agriculture Ecosystems \& Environment 105:235-242.

Schweiger, O., J. P. Maelfait, W. Van Wingerden, F. Hendrickx, R. Billeter, M. Speelmans, I. Augenstein, B. Aukema, S. Aviron, D. Bailey, R. Bukacek, F. Burel, T. Diekotter, J. Dirksen, M. Frenzel, F. Herzog, J. Liira, M. Roubalova, and R. Bugter. 2005. Quantifying the impact of environmental factors on arthropod communities in 
agricultural landscapes across organizational levels and spatial scales. Journal of Applied Ecology 42:1129-1139.

Shah, P. A., D. R. Brooks, J. E. Ashby, J. N. Perry, and I. P. Woiwod. 2003. Diversity and abundance of the coleopteran fauna from organic and conventional management systems in southern England. Agricultural and Forest Entomolgy 5:51-60.

Smith, J., S. G. Potts, B. A. Woodcock, and P. Eggleton. 2008. Can arable field margins be managed to enhance their biodiversity, conservation and functional value for soil macrofauna? Journal of Applied Ecology 45:269-278.

Stephens, P. A., R. P. Freckleton, A. R. Watkinson, and W. J. Sutherland. 2003. Predicting the response of farmland bird populations to changing food supplies. Journal of Applied Ecology 40:970-983.

Stoate, C., N. D. Boatman, R. J. Borralho, C. R. Carvalho, G. R. de Snoo, and P. Eden. 2001. Ecological impacts of arable intensification in Europe. Journal of Environmental Management 63:337-365.

Thorbek, P., and T. Bilde. 2004. Reduced numbers of generalist arthropod predators after crop management. Journal of Applied Ecology 41:526-538.

Tylianakis, J. M., A. M. Klein, T. Lozada, and T. Tscharntke. 2006. Spatial scale of observation affects alpha, beta and gamma diversity of cavity-nesting bees and wasps across a tropical land-use gradient. Journal of Biogeography 33:1295-1304.

Tylianakis, J. M., A. M. Klein, and T. Tscharntke. 2005. Spatiotemporal variation in the diversity of hymenoptera across a tropical habitat gradient. Ecology 86:3296-3302.

Veech, J., K. Summerville, T. Crist, and J. Gering. 2002. The additive partitioning of species diversity: recent revival of an old idea. Oikos 99:3-9.

Vickery, J., N. Carter, and R. J. Fuller. 2002. The potential value of managed cereal field margins as foraging habitats for farmland birds in the UK. Agriculture Ecosystems \& 
Environment 89:41-52.

Wagner, H. H., O. Wildi, and K. C. Ewald. 2000. Additive partitioning of plant species diversity in an agricultural mosaic landscape. Landscape Ecology 15:219-227.

Weiher, E., and A. Howe. 2003. Scale-dependence of environmental effects on species richness in oak savannas. Journal of Vegetation Science 14:917-920.

Wilson, J. D., M. J. Whittingham, and R. B. Bradbury. 2005. The management of crop structure: a general approach to reversing the impacts of agricultural intensification on birds? Ibis 147:453-463. 


\begin{abstract}
APPENDIX
$\alpha$ - and $\beta$-diversities within each region disregarding AI

The importance of $\alpha$ - and $\beta$-diversities for the species richness within each region is shown in figure S1. Here total diversity observed in each of the 9 European regions was mainly explained by $\beta$-diversity between farms ( $\left.\beta_{\text {farm }}, 78.08 \% \pm 4.99 \mathrm{SD}\right)$, while $\beta$-diversity between fields $\left(\beta_{\text {field }}, 13.31 \% \pm 4.99 \mathrm{SD}\right)$ and $\alpha$-diversity on the field $(13.05 \% \pm 2.7 \mathrm{SD})$ were less important.

Birds

Breeding bird territories for farmland species were determined using the three survey rounds (Supplementary Table 1). Three different criteria were used to define breeding bird territories depending on the species' detectability and breeding behaviour (Supplementary Table 1). To meet the criteria for assigning a breeding territory, species of category A had to be observed at least two times displaying territorial behaviour (foraging, calling, singing, conflicts indicating territory defence) at the same spot during different survey rounds. Species that were unlikely to be present during all the three survey visits because of their migration behaviour (e.g., long-distance migrants arriving relatively late) and species that were considered difficult to observe belong to category B. For this category, only one observation of territorial behaviour was required. Direct evidence of breeding activities was required for species of category $\mathrm{C}$.
\end{abstract}

\title{
Results of the analysis with a reduced dataset
}

We analysed a reduced dataset with only the data from Estonia, Germany (Göttingen), Germany (Jena), Netherland, Poland and Spain to test for effects of overlapping AI index values (Table 1). 
Table S1: Breeding bird species and the corresponding requirements for assigning breeding territories. A: at least two observations of birds displaying territorial behaviour at the same spot during different survey rounds; B: one observation of territorial behaviour (species unlikely to be present during all the three survey visits or species considered difficult to observe); C: direct evidence of breeding activities.

\begin{tabular}{|c|c|c|}
\hline English name & Scientific name & breeding category \\
\hline Blackbird & Turdus merula & A \\
\hline Blackcap & Sylvia atricapilla & A \\
\hline Bullfinch & Pyrrhula pyrrhula & A \\
\hline Blue Tit & Parus caeruleus & A \\
\hline Bluethroat & Luscinia svecica & B \\
\hline Black-tailed Godwit & Limosa limosa & A \\
\hline Barred Warbler & Sylvia nisoria & B \\
\hline Black Redstart & Phoenicurus ochruros & A \\
\hline Buzzard & Buteo buteo & C \\
\hline Carrion Crow & Corvus corone corone & C \\
\hline Corn Bunting & Miliaria calandra & A \\
\hline Chiffchaff & Phylloscopus collybita & A \\
\hline Collared Dove & Streptopelia decaocto & A \\
\hline Corncrake & Crex crex & B \\
\hline Chaffinch & Fringilla coelebs & A \\
\hline Crested Tit & Parus cristatus & A \\
\hline Cuckoo & Cuculus canorus & C \\
\hline Crested Lark & Galerida cristata & A \\
\hline Coot & Fulica atra & C \\
\hline Coal Tit & Parus ater & A \\
\hline Curlew & Numenius arquata & B \\
\hline Cetti's Warbler & Cettia cetti & A \\
\hline Dunnock & Prunella modularis & A \\
\hline Red-backed Shrike & Lanius collurio & B \\
\hline Fieldfare & Turdus pilaris & A \\
\hline Feral Pigeon & Columba livia domestica & A \\
\hline Fan-tailed Warbler & Cisticola juncidis & A \\
\hline Green Woodpecker & Picus viridis & A \\
\hline
\end{tabular}




\begin{tabular}{|c|c|c|}
\hline Great Bustard & Otis tarda & $\mathrm{B}$ \\
\hline Goldcrest & Regulus regulus & $A$ \\
\hline Grasshopper Warbler & Locustella naevia & $\mathrm{B}$ \\
\hline Goldfinch & Carduelis carduelis & A \\
\hline Greenfinch & Carduelis chloris & $A$ \\
\hline Great Spotted Woodpecker & Dendrocopos major & $A$ \\
\hline Great Tit & Parus major & $A$ \\
\hline Garden Warbler & Sylvia borin & $\mathrm{B}$ \\
\hline Hooded Crow & Corvus corone cornix & C \\
\hline House Martin & Delichon urbica & C \\
\hline House Sparrow & Passer domesticus & C \\
\hline Icterine Warbler & Hippolais icterina & $\mathrm{B}$ \\
\hline Jay & Garrulus glandarius & $\mathrm{C}$ \\
\hline Jackdaw & Corvus monedula & C \\
\hline Kestrel & Falco tinnunculus & $\mathrm{C}$ \\
\hline Lapwing & Vanellus vanellus & $A$ \\
\hline Little Bustard & Tetrax tetrax & $\mathrm{B}$ \\
\hline Long-eared Owl & Asio otus & $\mathrm{C}$ \\
\hline Little Grebe & Tachybaptus ruficollis & C \\
\hline Linnet & Carduelis cannabina & A \\
\hline Lesser Kestrel & Falco naumanni & C \\
\hline Little Owl & Athene noctua & C \\
\hline Long-tailed Tit & Aegithalos caudatus & B \\
\hline Lesser Whitethroat & Sylvia curruca & $A$ \\
\hline Mistle Thrush & Turdus viscivorus & A \\
\hline Mallard & Anas platyrhynchos & C \\
\hline Magpie & Pica pica & C \\
\hline Moorhen & Gallinula chloropus & $\mathrm{C}$ \\
\hline Montagu's Harrier & Circus pygargus & C \\
\hline Meadow Pipit & Anthus pratensis & A \\
\hline Marsh Harrier & Circus aeruginosus & C \\
\hline Mute Swan & Cygnus olor & C \\
\hline Marsh Tit & Parus palustris & $A$ \\
\hline
\end{tabular}




\begin{tabular}{|c|c|c|}
\hline Marsh Warbler & Acrocephalus palustris & $\mathrm{B}$ \\
\hline Bee-eater & Merops apiaster & $\mathrm{B}$ \\
\hline Nightingale & Luscinia megarhynchos & $\mathrm{B}$ \\
\hline Nuthatch & Sitta europaea & $A$ \\
\hline Serin & Serinus serinus & $A$ \\
\hline Ortolan Bunting & Emberiza hortulana & $\mathrm{B}$ \\
\hline Oystercatcher & Haematopus ostralegus & $A$ \\
\hline Golden Oriole & Oriolus oriolus & $B$ \\
\hline Grey Partridge & Perdix perdix & B \\
\hline Pied Flycatcher & Ficedula hypoleuca & $B$ \\
\hline Pheasant & Phasianus colchicus & $A$ \\
\hline Penduline Tit & Remiz pendulinus & $\mathrm{B}$ \\
\hline Pied/White Wagtail & Motacilla alba & $A$ \\
\hline Quail & Coturnix coturnix & $\mathrm{B}$ \\
\hline Great Reed Warbler & Acrocephalus arundinaceus & $B$ \\
\hline Robin & Erithacus rubecula & $A$ \\
\hline Reed Bunting & Emberiza schoeniclus & $A$ \\
\hline Redwing & Turdus iliacus & $A$ \\
\hline Red-legged Partridge & Alectoris rufa & $\mathrm{B}$ \\
\hline Raven & Corvus corax & $\mathrm{C}$ \\
\hline Rook & Corvus frugilegus & $\mathrm{C}$ \\
\hline Roller & Coracias garrulus & $\mathrm{B}$ \\
\hline Redstart & Phoenicurus phoenicurus & $A$ \\
\hline Reed Warbler & Acrocephalus scirpaceus & $A$ \\
\hline Skylark & Alauda arvensis & $A$ \\
\hline Stonechat & Saxicola torquata & $A$ \\
\hline Stock Dove & Columba oenas & $A$ \\
\hline Spotted Flycatcher & Muscicapa striata & $B$ \\
\hline Starling & Sturnus vulgaris & $\mathrm{C}$ \\
\hline Sparrowhawk & Accipiter nisus & $\mathrm{C}$ \\
\hline Swift & Apus apus & $\mathrm{C}$ \\
\hline Siskin & Carduelis spinus & $A$ \\
\hline Swallow & Hirundo rustica & $\mathrm{C}$ \\
\hline
\end{tabular}




\begin{tabular}{|c|c|c|}
\hline Sand Martin & Riparia riparia & $\mathrm{C}$ \\
\hline Scarlet Rosefinch & Carpodacus erythrinus & $\mathrm{B}$ \\
\hline Spotless Starling & Sturnus unicolor & $\mathrm{C}$ \\
\hline Song Thrush & Turdus philomelos & A \\
\hline Short-toed Lark & Calandrella brachydactyla & $A$ \\
\hline Sedge Warbler & Acrocephalus schoenobaenus & $A$ \\
\hline Treecreeper & Certhia familiaris & $A$ \\
\hline Turtle Dove & Streptopelia turtur & $\mathrm{B}$ \\
\hline Thrush Nightingale & Luscinia luscinia & $\mathrm{B}$ \\
\hline Tree Pipit & Anthus trivialis & A \\
\hline Tawny Pipit & Anthus campestris & $\mathrm{B}$ \\
\hline Tree Sparrow & Passer montanus & $A$ \\
\hline Savi's Warbler & Locustella luscinioides & $B$ \\
\hline River Warbler & Locustella fluviatilis & B \\
\hline Wheatear & Oenanthe oenanthe & A \\
\hline White-backed Woodpecker & Dendrocopos leucotos & $\mathrm{B}$ \\
\hline White wagtail & Motacilla alba & $A$ \\
\hline Whinchat & Saxicola rubetra & A \\
\hline Whitethroat & Sylvia communis & $A$ \\
\hline Woodlark & Lullula arborea & $A$ \\
\hline Wood Warbler & Phylloscopus sibilatrix & $A$ \\
\hline Woodpigeon & Columba palumbus & $A$ \\
\hline Wren & Troglodytes troglodytes & $A$ \\
\hline Willow Tit & Parus montanus & $A$ \\
\hline Willow Warbler & Phylloscopus trochilus & A \\
\hline Wryneck & Jynx torquilla & $\mathrm{B}$ \\
\hline Yellowhammer & Emberiza citrinella & $A$ \\
\hline Yellow Wagtail & Motacilla flava & $A$ \\
\hline
\end{tabular}


Table S2: Effect of AI level (low, medium and high) on the $\alpha$ - and $\beta$-diversities of the three taxa (absolute values) from the reduced dataset. $F$ - and p-values and denominator degrees of freedom (d.f.) of conditional $F$ tests performed on linear mixed effect models are given. Significant differences between species richness estimates are marked by different alphabetic characters. n.s. not significant, (.) $\mathrm{P}<0.1,{ }^{*} \mathrm{P}<0.05 ; * * \mathrm{P}<0.01$; $* * * \mathrm{P}<0.001$.

\begin{tabular}{llclccc}
\hline \multirow{2}{*}{ Taxon } & \multirow{2}{*}{ Scale } & d.f. & $F$-Value & Low & Medium & High \\
\cline { 6 - 7 } & & & & & & \\
\cline { 5 - 6 } Plants & $\alpha$ & 166 & $12.77^{* * *}$ & $9.74_{\mathrm{a}}$ & $7.18_{\mathrm{b}}$ & $5.13_{\mathrm{c}}$ \\
Plants & $\beta_{\text {field }}$ & 166 & $3.57^{*}$ & $9.79_{\mathrm{a}}$ & $9.17_{\mathrm{ab}}$ & $7.17_{\mathrm{b}}$ \\
Plants & $\beta_{\text {farm }}$ & 166 & $13.92^{* * *}$ & $42.56_{\mathrm{a}}$ & $47_{\mathrm{b}}$ & $38.17_{\mathrm{c}}$ \\
Plants & $\beta_{\text {region }}$ & 10 & $18.34^{* * *}$ & $179.26_{\mathrm{a}}$ & $173.56_{\mathrm{a}}$ & $136.64_{\mathrm{b}}$ \\
Carabids & $\alpha$ & 166 & 2.38 n.s. & 6.42 & 6.14 & 5.66 \\
Carabids & $\beta_{\text {field }}$ & 166 & 0.62 n.s. & 7.61 & 8.12 & 7.73 \\
Carabids & $\beta_{\text {farm }}$ & 166 & $4.43^{*}$ & $25.65_{\mathrm{a}}$ & $25.55_{\mathrm{a}}$ & $28.13_{\mathrm{b}}$ \\
Carabids & $\beta_{\text {region }}$ & 10 & $3.16()$. & 105.83 & 97.5 & 99.5 \\
Birds & $\alpha$ & 158 & 0.04 n.s. & 5.60 & 5.77 & 5.59 \\
Birds & $\beta_{\text {farm }}$ & 158 & $7.21^{* *}$ & $22.43_{\mathrm{a}}$ & $18.16_{\mathrm{b}}$ & $17.89_{\mathrm{b}}$ \\
Birds & $\beta_{\text {region }}$ & 10 & $5.27^{*}$ & $62.67_{\mathrm{a}}$ & $50.83_{\mathrm{b}}$ & $50.5_{\mathrm{b}}$ \\
\hline
\end{tabular}


Table S3: Effect of AI-level on the relative contribution ( $\%$ of total) of $\alpha$ - and $\beta$-diversities to the $\gamma$-diversity of each taxa within each AI level of the reduced dataset. $F$ - and p-values and denominator degrees of freedom (d.f.) of conditional $F$ tests performed on linear mixed effect models are given. Significant differences between $\%$ of total species richness estimates are marked by different alphabetic characters. n.s. not significant, $* \mathrm{P}<0.05$; $* * \mathrm{P}<0.01 ; * * * \mathrm{P}<0.001$.

\begin{tabular}{ccccccc}
\hline & & & & \multicolumn{3}{c}{$\%$ of total species richness } \\
Taxon & Scale & d.f. & F-Value & \multicolumn{3}{c}{ estimates } \\
\cline { 5 - 7 } & & & & Low & Medium & High \\
\hline Plants & $\alpha$ & 166 & $5.10^{* *}$ & $3.58_{\mathrm{a}}$ & $2.73_{\mathrm{b}}$ & $2.39_{\mathrm{b}}$ \\
Plants & $\beta_{\text {field }}$ & 166 & 0.13 n.s. & 4.12 & 3.90 & 3.92 \\
Plants & $\beta_{\text {farm }}$ & 166 & 1.76 n.s. & 16.48 & 18.41 & 18 \\
Plants & $\beta_{\text {region }}$ & 10 & 0.01 n.s. & 72.67 & 72.45 & 72.54 \\
Carabids & $\alpha$ & 166 & 1.96 n.s. & 4.30 & 4.40 & 3.95 \\
Carabids & $\beta_{\text {field }}$ & 166 & 2.46 n.s. & 5.09 & 5.81 & 5.38 \\
Carabids & $\beta_{\text {farm }}$ & 166 & $6.52^{* *}$ & $17.13_{\mathrm{ab}}$ & $18.27_{\mathrm{a}}$ & $19.55_{\mathrm{b}}$ \\
Carabids & $\beta_{\text {region }}$ & 10 & 0.20 n.s. & 70.56 & 69.64 & 69.1 \\
Birds & $\alpha$ & 158 & 2.80 n.s. & 6.63 & 8.63 & 8.29 \\
Birds & $\beta_{\text {farm }}$ & 158 & 1.33 n.s. & 23.82 & 25.73 & 25.51 \\
\hline Birds & $\beta_{\text {region }}$ & 10 & 0.05 n.s. & 65.28 & 65.17 & 66.45 \\
\hline
\end{tabular}


Table S4: Results of paired t-tests comparing the relative contribution of each scale to taxon specific total species richness of the reduced dataset between the different taxa; n.s. not significant, (.) $\mathrm{P}<0.1$, $* \mathrm{P}<0.05 ; * * \mathrm{P}<0.01 ; * * \mathrm{P}<0.001 ; \mathrm{P}=$ plants, $\mathrm{C}=$ carabids, $\mathrm{B}=$ birds

\begin{tabular}{ccccc}
\hline Scale & Taxon & t-value & df & $\begin{array}{c}\text { Direction of } \\
\text { effect }\end{array}$ \\
\hline$\alpha$ & Plants - Carabids & $-7.81^{* * *}$ & 866 & $\mathrm{P}<\mathrm{C}$ \\
$\beta_{\text {field }}$ & Plants - Carabids & $-7.72^{* * *}$ & 866 & $\mathrm{P}<\mathrm{C}$ \\
$\beta_{\text {farm }}$ & Plants - Carabids & -086 n.s.S & 173 & $\mathrm{P}=\mathrm{C}$ \\
$\beta_{\text {farm }}$ & Plants - Birds & $-6.87^{* * *}$ & 168 & $\mathrm{~B}>\mathrm{P}$ \\
$\beta_{\text {farm }}$ & Carabids - Birds & $-6.65^{* * *}$ & 168 & $\mathrm{~B}>\mathrm{C}$ \\
$\beta_{\text {region }}$ & Plants - Carabids & 1.05 n.s. & 17 & $\mathrm{P}=\mathrm{C}$ \\
$\beta_{\text {region }}$ & Plants - Birds & $1.88()$. & 17 & $\mathrm{~B}=\mathrm{P}$ \\
$\beta_{\text {region }}$ & Carabids - Birds & 1.32 n.s. & 17 & $\mathrm{~B}=\mathrm{C}$ \\
\hline
\end{tabular}



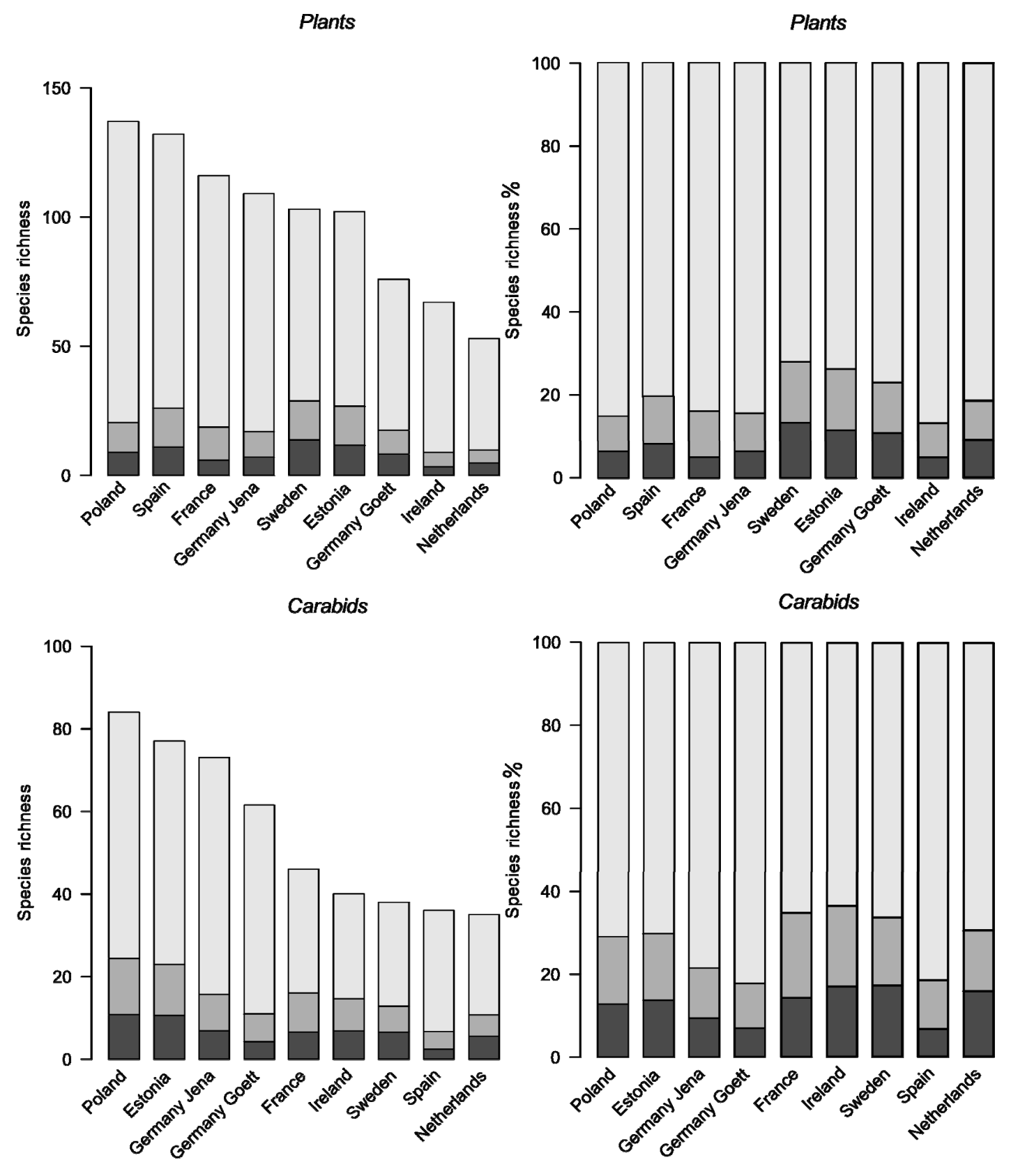

Birds

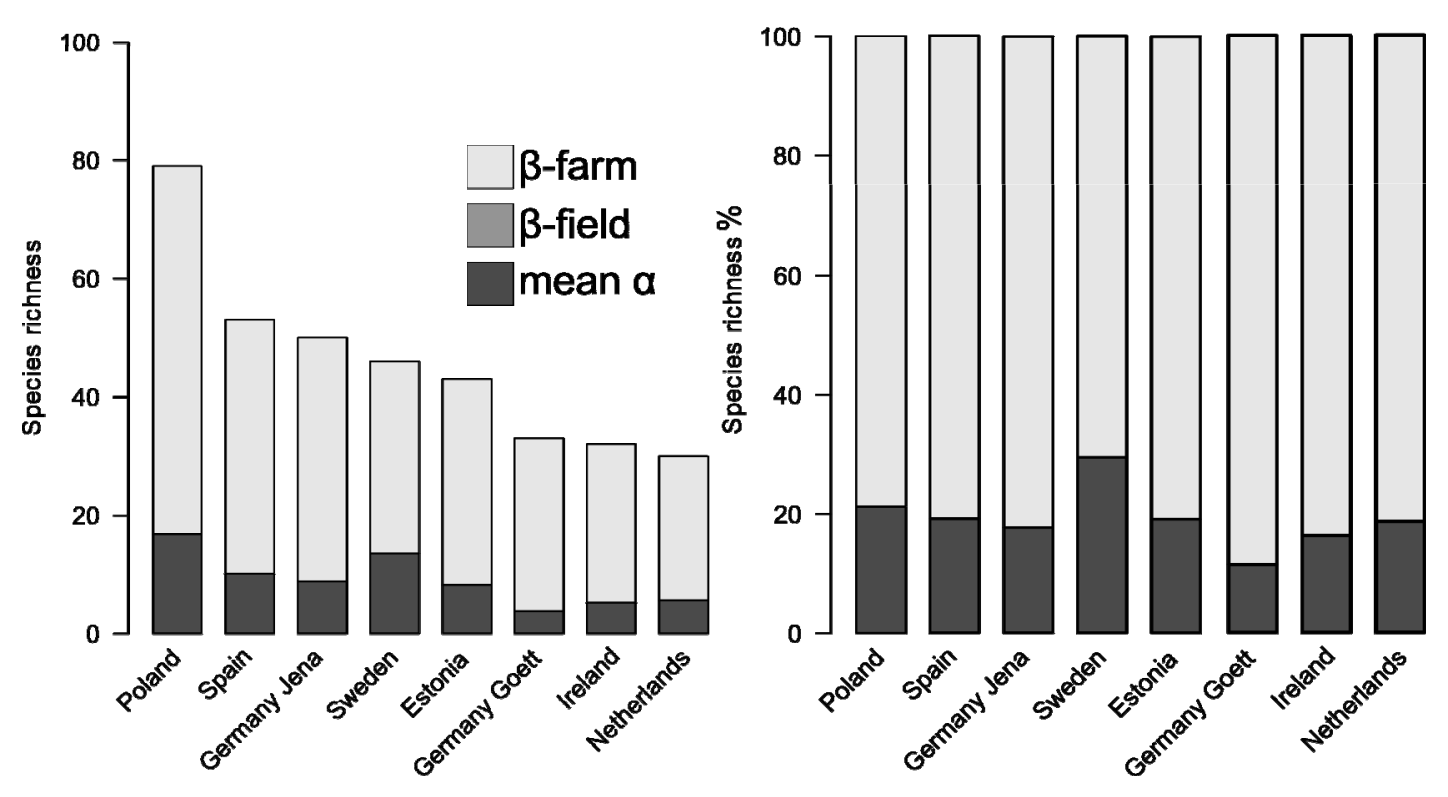


Figure S1: Partitioning of diversity of plants, carabids and birds across the nine regions, separated into $\alpha$ diversity on the field and $\beta$-diversity between fields $\left(\beta_{\text {field }}\right)$ and farms $\left(\beta_{\text {farm }}\right)$.

Relative contribution (\%) of $\alpha$ - and $\beta$-diversities to the $\gamma$-diversity of the three taxa across all regions, separated into $\alpha$-diversity on the field and $\beta$-diversity between fields $\left(\beta_{\text {field }}\right)$ and farms $\left(\beta_{\text {farm }}\right)$. 


\section{Chapter 3}

\section{DOES SOIL BIOTA BENEFIT FROM ORGANIC FARMING IN COMPLEX VS. SIMPLE LANDSCAPES?}

A. Flohre, M. Rudnick, G. Traser, T. Tscharntke and T. Eggers 


\begin{abstract}
Agri-environmental schemes like organic farming can counteract detrimental effects of agricultural intensification on farmland biodiversity. Enhancing biodiversity with agrienvironmental schemes is hypothesized to be more efficient in simple than complex landscapes, a pattern confirmed for many aboveground taxa. Although belowground biodiversity is an important part of the agroecosystem, studies on the interacting effects of local and landscape intensification on the belowground detritivore community, including bacteria, collembolans and earthworms are lacking

We sampled diversity and abundance of arable weeds, earthworms and collembolans, soil respiration rate and microbial biomass in 12 pairs of organically and conventionally managed fields in landscapes differing in structural complexity. Organic farming significantly enhanced species richness of arable weeds, while conventional farming enhanced soil respiration. We found that the landscape context plays a significant role in shaping effects of organic vs. conventional farming on soil biota, although collembola abundance was enhanced by organic farming independently of landscape context. Earthworm species richness in simple landscapes, where predation pressure is reduced, was enhanced by organic farming, whereas in complex landscapes, conventional farming, which often causes reduced predation, fostered earthworm species richness. As the same pattern was found for microbial carbon biomass, earthworms may have enhanced microbial biomass. In contrast to earthworm and microbial diversity, aboveground biodiversity benefits most from organic farming in simple landscapes. In general, organic farming appears to be more efficient in conserving aboveground than belowground diversity, which could be due to the enormous functional redundancy of the belowground community and therefore high resilience and resistance to anthropogenic disturbances.
\end{abstract}

Key words: agri-environmental schemes, soil, biodiversity, landscape complexity, organic farming, earthworms, collembola, springtails, microbial biomass 


\section{INTRODUCTION}

Effects of local agricultural intensification and landscape complexity on the biodiversity of agricultural landscapes have been a major topic in ecological research for the last decade. In most cases, agricultural intensification and landscape simplification lead to a loss of biodiversity (Stoate et al. 2001, Benton et al. 2003, Foley et al. 2005). Agri-environmental schemes (AES), for example organic farming often counteract these detrimental effects (Bengtsson et al. 2005, Hole et al. 2005). AES aimed at enhancing biodiversity on the fields are hypothesized to be more efficient in simple landscapes compared to complex landscapes (Tscharntke et al. 2005a). In complex landscapes the beneficial effects of AES are blurred by the overall higher biodiversity due to the higher amount of semi-natural habitats and environmental heterogeneity. This hypothesis is confirmed for plants (Roschewitz et al. 2005), pollinators (Holzschuh et al. 2007, Rundlof et al. 2008), spiders (Schmidt et al. 2005, 2008), carabid beetles (Purtauf et al. 2005b) and butterflies (Rundlof and Smith 2006).

Although belowground biodiversity is an important and integrative part of the agroecosystem, studies on the interacting effects of local and landscape intensification on bacteria, collembolans and earthworms, which are important belowground detritivores (Rusek 1998, Jouquet et al. 2006, van der Heijden et al. 2008) are lacking. Likewise studies on the effect of landscape complexity on belowground soil biota in general are scarce, although studies on soil surface inhabiting fauna, e.g. carabids and spiders were done (Ostman et al. 2001, Purtauf et al. 2005b, Schmidt et al. 2005).

Current knowledge on belowground biodiversity suggests that soil communities are highly resistant to anthropogenic disturbances due to the enormous functional redundancy in belowground food webs (Swift et al. 2004, Bardgett 2005, Fitter et al. 2005). However, effects of agricultural intensification on belowground biota are not as predictable as effects of agricultural intensification on aboveground biota. For example, positive effects of organic farming on belowground decomposer diversity might only be evident years after the conversion from conventional farming to organic farming (Mader et al. 2002, Bardgett 2005, Birkhofer et al. 2008) and for soil communities confounding factors like soil type seem to be relatively more important than management (Bardgett 2005, van Diepeningen et al. 2006).

Belowground biodiversity is important for ecosystem functioning including decomposition, soil fertility and geochemical cycling. A better understanding of the factors regulating belowground biodiversity would help to predict risks for nutrient cycling and soil fertility through local agricultural intensification and landscape simplification. 
We studied the effects of organic and conventional farming and landscape context on the species richness and abundance of arable weeds and belowground biota, namely collembola, earthworms, microbial biomass and soil respiration. Results from aboveground biota suggest that (i), belowground biota is enhanced under organical management, (ii), landscape simplification leads to reduced belowground biota and (iii), the efficiency of organic farming in conserving biodiversity is less pronounced in complex compared to simple landscapes. For the soil biota, we expect less pronounced effects than are known for aboveground organisms, following findings of, for example, Bardgett (2005), Fitter et al. (2005).

\section{MATERIAL AND MethodS}

\section{Site description}

Samples were taken in summer 2008 from twelve pairs of either organically or conventionally managed agricultural fields in the vicinity of the city of Göttingen (Lower Saxony, Germany). Differences between management types were assessed with standardized questionnaires sent to the farmers. Organically managed fields did not receive mineral fertilizer or pesticide input and were organically managed at least for six years (established between 1985 and 2002) which should be long enough to avoid delayed effects of conversion from conventional to organical farming (Mader et al. 2002). All fields had similar soil types (Cambisols) and were planted with winter-wheat. Landscape structure in 500 and $100 \mathrm{~m}$ radius around the sampled fields were measured on the basis of official topographical maps (DGK 5, Deutsche Grundkarte, Landesvermessung und Geobasisinformation Lower Saxony, Germany; 1:5000) using ArcGIS 9.2 (ESRI). Percentage of agricultural fields, which is closely related to habitat type diversity, was used as an indicator for landscape complexity (Thies and Tscharntke 1999, Thies et al. 2003, Roschewitz et al. 2005). Percentage arable land ranged between 33 - 100 percent in $100 \mathrm{~m}$ radius and $24-72$ percent in $500 \mathrm{~m}$ radius around the fields (Appendix, table S1). Four samples per field were taken in ten meter distance to the field margin and pooled and homogenised to account for small scale variations in the soil structure and bacterial communities. Each sample was then divided into two subsamples. One was used for determination of microbial biomass and one for analysis of soil chemical properties. Subsamples for the determination of the microbial biomass were stored at $+4{ }^{\circ} \mathrm{C}$, the other subsamples at $-20^{\circ} \mathrm{C}$. To determine soil dry weight, $10 \mathrm{~g}$ of every soil sample was oven dried till constant weight was reached. 


\section{Sampling of soil fauna and aboveground plant cover}

$380 \mathrm{~cm}^{3}$ soil cores were taken from each sampling point and springtails (Insecta, Collembola) were extracted using MacFadyen's high gradient extraction and identified to species level. The protocol was as following; start at $17.5^{\circ} \mathrm{C}$, increasing temperature in $2.5^{\circ} \mathrm{C}$ steps per day for five days, increasing temperature in $5{ }^{\circ} \mathrm{C}$ steps per day for six days.

On each sampling point a soil monolith $(2 \mathrm{~m}$ width $* 1 \mathrm{~m}$ length $* 25 \mathrm{~cm}$ depth) was dug out using a spade and earthworms were hand sorted, stored in $70 \%$ ethanol and identified to species level.

On each field the number of plant species was counted in a $2 \mathrm{~m}^{2}$ plot situated in $10 \mathrm{~m}$ distance from the field edge.

\section{Microbial biomass \& activity}

The microbial biomass was estimated using the chloroform fumigation extraction method (Jenkinson et al. 2004). The dissolved organic carbon and dissolved organic nitrogen were quantified with the DIMATOC 100 (Dimatec Analysentechnik GmbH, Essen). Soil respiration rate (microbial activity) was determined gravimetrically, using a soda-lime based method (Grogan 1998). In brief, we placed oven dried soda-lime in $50 \mathrm{ml}$ beakers under a transparent plastic chamber covering $20 \mathrm{~cm}^{2}$ of bare ground. After $24 \mathrm{~h}$ the increase in sodalime dry weight due to absorption of $\mathrm{CO} 2$ was determined. Soil respiration measurements were performed in four replicates, microbial biomass in triplicates. Statistical analyses were based on derived mean values.

\section{Statistical analysis}

Linear mixed effects models (Pinheiro and Bates 2000) were used to test the effects of management type and landscape on the species richness of plants, the species richness and abundance of collembolans, soil respiration rate and bacterial biomass carbon. Management type was included as a two level factor, ecological and conventional. Landscape structure, quantified either at $100 \mathrm{~m}$ and $500 \mathrm{~m}$ radius around the plots, was included as a continuous variable (table1). Because observations were not independent from each other, fields were nested within regions and included as random factor into the models.

Model assumptions were checked using diagnosis plots and dependent variables were either log- or square-root transformed to account for non-normal distribution and heteroscedasticity 
when necessary. The significance of the variables in each model was determined by using conditional $F$ tests, where the null model was tested against models with the variables.

All analyses were performed using R 2.8.1 (R Development Core Team 2008) and the package nlme.

\section{Results}

Organic farming significantly increased species richness of weeds as well as abundance of collembola. In contrast, soil respiration rate was higher under conventional management, and also earthworm species richness increased, with marginal significance, under conventional management (table 1).

Landscape complexity effects were only apparent at $100 \mathrm{~m}$ radius. Soil respiration rates increased with increasing landscape simplification (i.e. increasing \% of arable land, table 1). However, we found several significant interactions between landscape complexity and management type (table 1). There was a trend to decreased species richness of weeds on organically managed fields with landscape simplification, while conventionally managed field species richness was low independently of landscape (figure1). Landscape simplification in $100 \mathrm{~m}$ radius increased microbial biomass carbon in organically managed fields and decreased it in conventionally managed fields (figure 2). The same pattern could be found for earthworm species richness in $500 \mathrm{~m}$ radius (figure 3). 


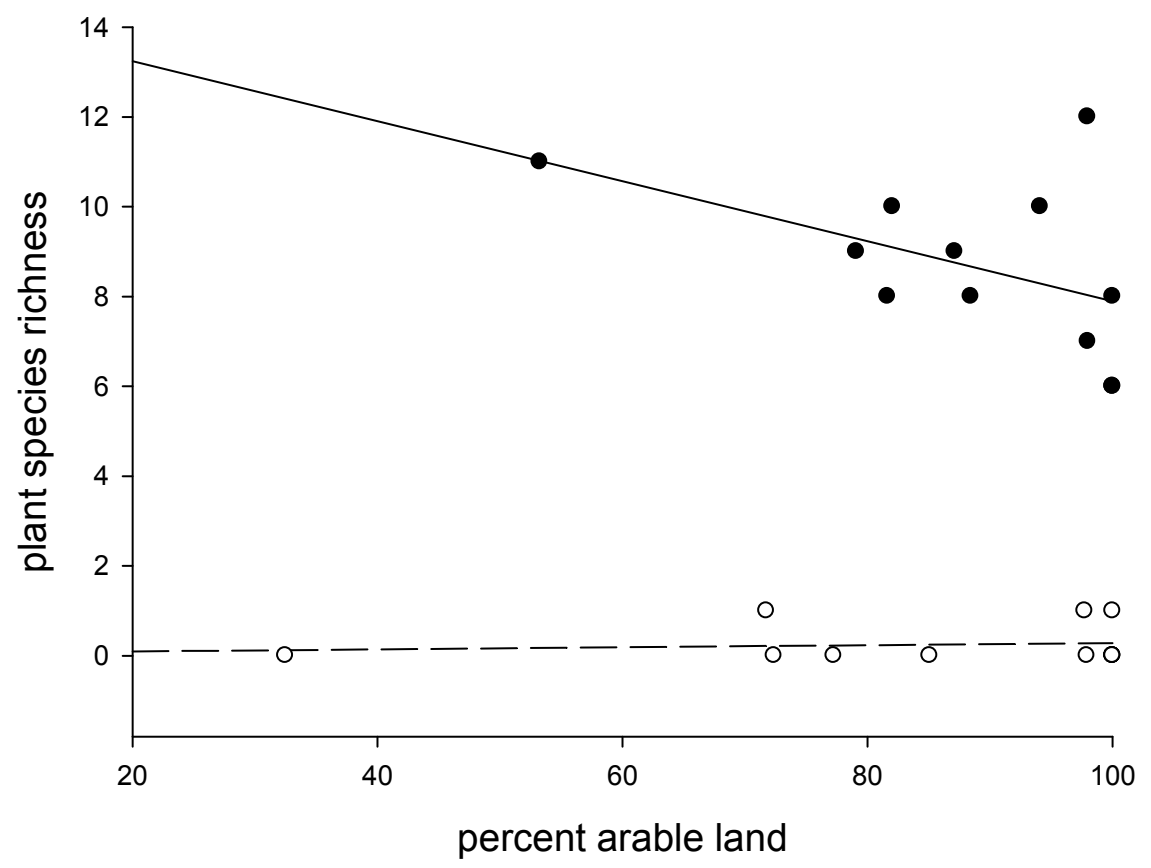

Figure 1: Correlation between percent arable land in $100 \mathrm{~m}$ radius around the sampling points and plant species richness in conventionally (open circles, dashed regression line) and organically (filled circles, solid regression line) managed fields.

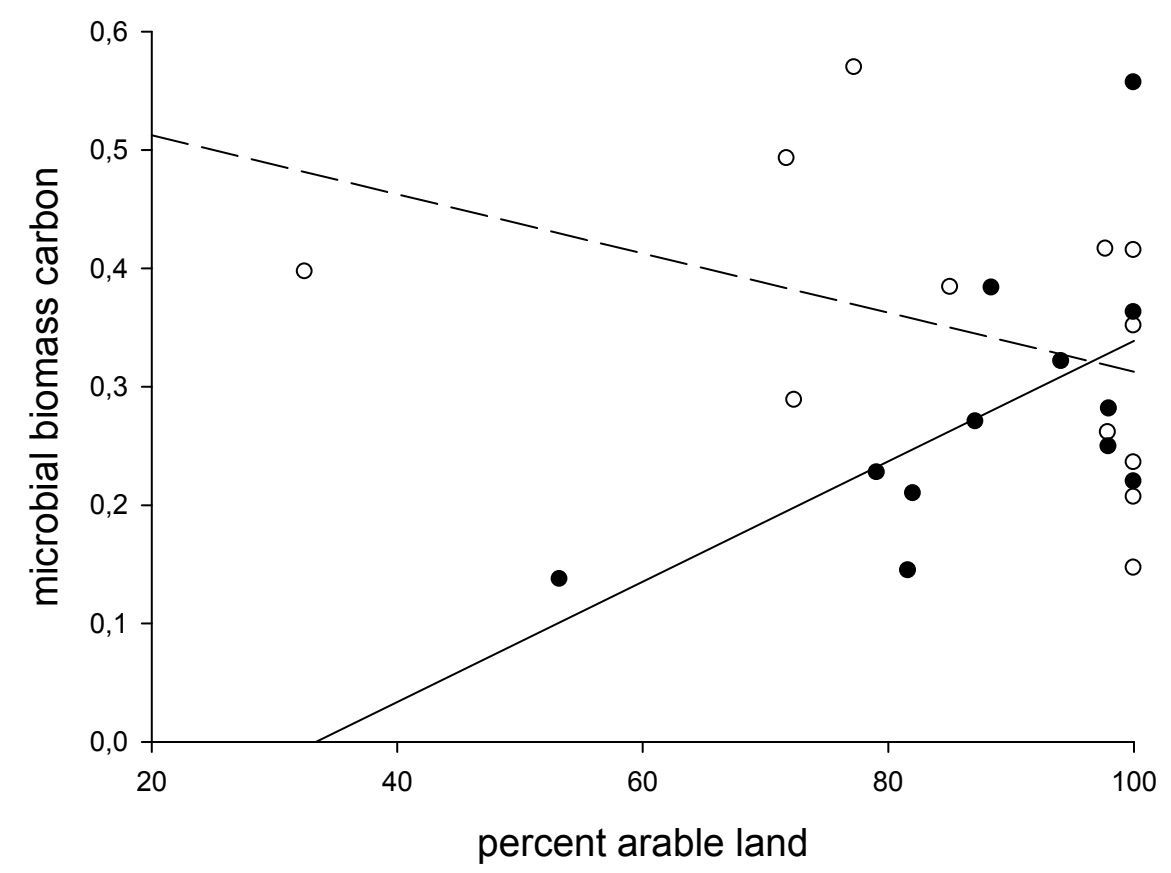

Figure 2: Correlation between percent arable land in $100 \mathrm{~m}$ radius around the sampling points and microbial biomass carbon in conventionally (open circles, dashed regression line) and organically (filled circles, solid regression line) managed fields. 


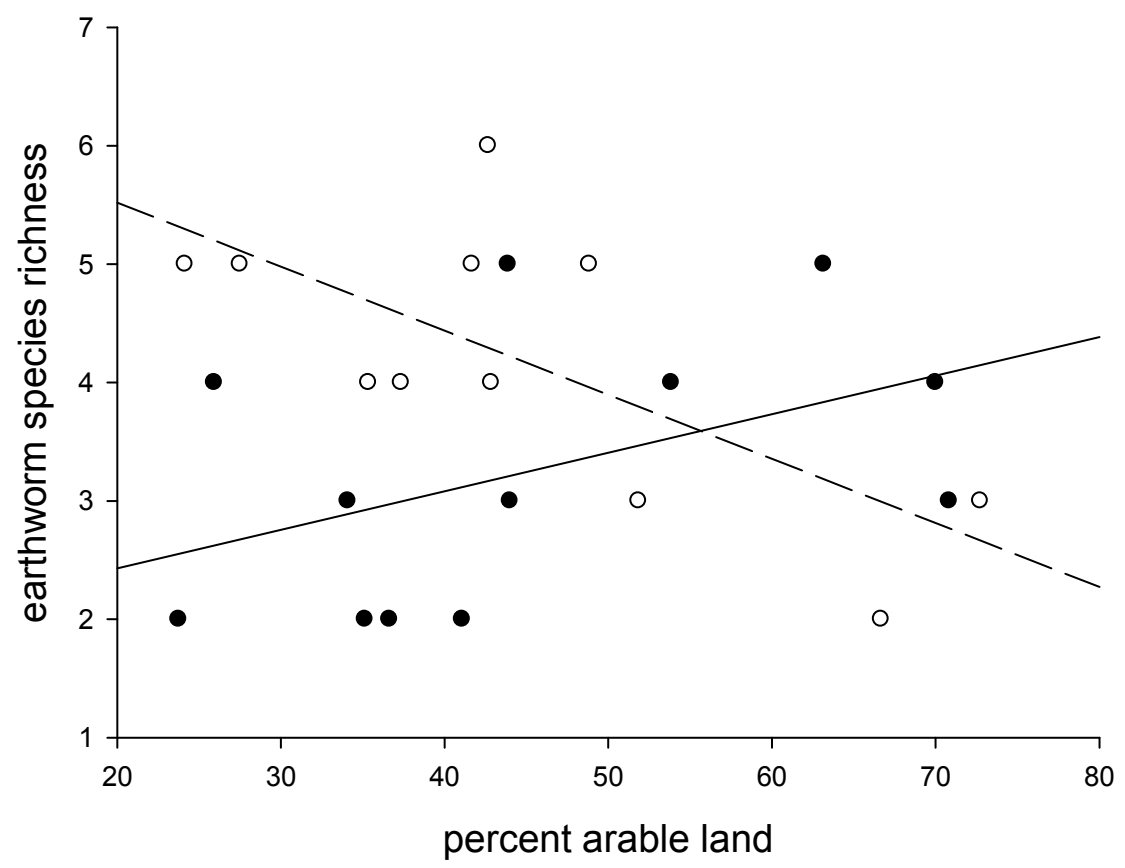

Figure 3: Correlation between percent arable land in $500 \mathrm{~m}$ radius around the sampling points and earthworm species richness in conventionally (open circles, dashed regression line) and organical (filled circles, solid regression line) managed fields.

Table 1: Effects of management type (c, conventional; o, organical), landscape complexity (sl, simple; cl, complex) at two radii and the interactions between management type and landscape on microbial biomass (Cmic), soil respiration and species richness (sr) and abundance (ab) of earthworms, collembolans and plants. $F$ and p-values and degrees of freedom of conditional $F$ tests performed on linear mixed effect models are given. n.s. not significant, $(*) \mathrm{P}<0.1, * \mathrm{P}<0.05 ; * * \mathrm{P}<0.01 ; * * * \mathrm{P}<0.001$; Cmic: microbial biomass carbon, sr species richness, ab abundance

\begin{tabular}{|c|c|c|c|c|c|c|c|}
\hline \multirow[b]{2}{*}{ Response } & \multirow{2}{*}{\multicolumn{2}{|c|}{ Management type }} & \multicolumn{3}{|c|}{ Landscape } & \multicolumn{2}{|c|}{ Interaction } \\
\hline & & & $100 \mathrm{~m}$ radiu & & $500 \mathrm{~m}$ radius & $100 \mathrm{~m}$ radius & $500 \mathrm{~m}$ radius \\
\hline Cmic & $\mathrm{F}_{1,7}=2.78$, n.s. & & $\mathrm{F}_{1,7}=0.00$, n.s. & & $\mathrm{F}_{1,7}=0.05$, n.s. & $\mathrm{F}_{1,7}=11.21^{* *}$ & $\mathrm{~F}_{1,7}=2.71$, n.s. \\
\hline Respiration & $\mathrm{F}_{1,7}=6.22^{*}$ & $c>0$ & $\mathrm{~F}_{1,7}=5.81^{*}$ & $\mathrm{sl}>\mathrm{cl}$ & $\mathrm{F}_{1,7}=0.04$, n.s. & $\mathrm{F}_{1,7}=0.07$, n.s. & $\mathrm{F}_{1,7}=3.50$, n.s. \\
\hline Earthworm sr & $\mathrm{F}_{1,6}=4.94,\left(^{*}\right)$ & $c>0$ & $\mathrm{~F}_{1,6}=0.04$, n.s. & & $\mathrm{F}_{1,6}=0.16$, n.s. & $\mathrm{F}_{1,6}=0.4$, n.s. & $\mathrm{F}_{1,6}=10.03 *$ \\
\hline Earthworm ab & $\mathrm{F}_{1,6}=0.15$, n.s. & & $\mathrm{F}_{1,6}=0.16$, n.s. & & $\mathrm{F}_{1,6}=0.06$, n.s. & $\mathrm{F}_{1,6}=0.47$, n.s. & $\mathrm{F}_{1,6}=0.18$, n.s. \\
\hline Collembola sr & $\mathrm{F}_{1,7}=0.44$, n.s. & & $\mathrm{F}_{1,7}=1.39$, n.s. & & $\mathrm{F}_{1,7}=1.15$, n.s. & $\mathrm{F}_{1,7}=2.45$, n.s. & $\mathrm{F}_{1,7}=0.92$, n.s. \\
\hline Collembola ab & $\mathrm{F}_{1,7}=8.77^{*}$ & $\mathrm{c}<\mathrm{o}$ & $\mathrm{F}_{1,7}=0.00$, n.s. & & $\mathrm{F}_{1,7}=0.30$, n.s. & $\mathrm{F}_{1,7}=1.27$, n.s. & $\mathrm{F}_{1,7}=1.39$, n.s. \\
\hline Plants sr & $\mathrm{F}_{1,7}=827.96 * * *$ & $\mathrm{c}<\mathrm{o}$ & $\mathrm{F}_{1,7}=0.32$, n.s. & & $\mathrm{F}_{1,7}=2.54$, n.s. & $\mathrm{F}_{1,7}=3.82(*)$ & $\mathrm{F}_{1,7}=2.21$, n.s. \\
\hline
\end{tabular}




\section{DisCUSSION}

\section{Effects of management system}

Our results show that organical farming, although effective in conserving aboveground plant species richness (as shown by our data) and many other aboveground organisms (Bengtsson et al. 2005) does not have equally strong effects on belowground biota. Out of microbial biomass, soil respiration, diversity and abundance of earthworms and collembolans, only the in-field abundance of collembolans was slightly enhanced under organic farming. Collembola are an important part of the belowground decomposer system and might benefit from the higher input of organic fertilizer (i.e. manure) and more complex plant litter composition on organic fields due to higher arable weed species richness (Gabriel et al. 2006). In contrast, the belowground microbial activity, as indicated by soil respiration, was enhanced under conventional farming. It is known that agricultural intensification, such as tillage, anthropogenic fertilizer etc., leads to a shift from a fungal dominated decomposition pathway under organical farming to a more bacterial dominated pathway (Bardgett 2005, Moore et al. 2005). Higher metabolism rates in bacterial dominated decomposer communities could have been responsible for the enhancement in soil respiration.

\section{Effects of landscape complexity and interactions with management system}

Complex landscapes have a profoundly bigger species pool than simplified landscapes, which has been shown for many species groups (Weibull et al. 2003, Dauber et al. 2005, Purtauf et al. 2005, Roschewitz et al. 2005, Schmidt et al. 2005, Hendrickx et al. 2007, Holzschuh et al. 2007). Landscape complexity enhances spillover from semi-natural habitats to adjacent fields (Tscharntke et al. 2005a, Tscharntke et al. 2005b), counteracting detrimental effects of farming for the within-field community.

Our study supports this view in that plant species richness in organic fields decreased with increasing landscape simplification, while in conventional fields it was generally very low.

In contrast, microbial biomass and earthworm species richness increased in organic fields with landscape simplification, whereas conventional fields showed the opposite pattern. Reduced earthworm richness in organic fields of complex landscapes can be related to predation. In complex landscapes, predation on earthworms is likely to be higher than in simple landscapes, as earthworm predators such as carabid beetles (Lukasiewicz 1996, Symondson et al. 2000) or birds have higher densities in complex landscapes (Vickery et al. 2002, Purtauf et al. 2005a, Purtauf et al. 2005b, Barbaro et al. 2007, Batary et al. 2007). In 
conventional fields, agrochemical input may have reduced such predation pressure (Bengtsson et al. 2005), allowing the expected positive relationship of earthworm richness and landscape complexity.

Earthworms influence the microbial community composition and biomass, as earthworms casts lead to higher fungal and bacterial density and diversity (Tiwari and Mishra 1993, McLean and Parkinson 1998, Tiunov and Scheu 1999, Savin et al. 2004, Marhan et al. 2007). This appears to be why earthworm species richness and microbial biomass pattern were so closely related.

In contrast to aboveground biota, where organic farming is most efficient in conserving biodiversity in simple landscapes and biodiversity is high everywhere in complex landscapes (Tscharntke et al. 2005a), earthworm species richness and microbial biomass were also efficiently enhanced by organic farming in simple landscapes, whereas diversity on organic fields was lower than on conventional fields in complex landscapes. However, in relative terms, our data show that organic farming was more efficient in conserving aboveground than belowground biodiversity, which could be due to the enormous functional redundancy of the belowground community and therefore high resilience and resistance to anthropogenic disturbances (Fitter et al. 2005).

\section{ACKNOWLEDGEMENTS}

We thank Heinz-Christian Fründ and Rudolf Oprée for help with the microbial biomass analyses, Antje Möhlmeyer for assistance in the lab, the farmers for allowing us to work on their fields and the biolog programme (BIOPLEX http://www.uni-giessen.de/bioplex) of the German Federal Ministry of Education and Science (BMBF) for funding.

\section{REFERENCES}

Barbaro, L., J. P. Rossi, F. Vetillard, J. Nezan, and H. Jactel. 2007. The spatial distribution of birds and carabid beetles in pine plantation forests: the role of landscape composition and structure. Journal of Biogeography 34:652-664.

Bardgett, R. D. 2005. The Biology of Soil: A community and ecosystem approach. Oxford 
University Press, Oxford.

Batary, P., A. Baldi, G. Szel, A. Podlussany, I. Rozner, and S. Erdos. 2007. Responses of grassland specialist and generalist beetles to management and landscape complexity. Diversity and Distributions 13:196-202.

Bengtsson, J., J. Ahnstrom, and A. C. Weibull. 2005. The effects of organic agriculture on biodiversity and abundance: a meta-analysis. Journal of Applied Ecology 42:261-269.

Benton, T. G., J. A. Vickery, and J. D. Wilson. 2003. Farmland biodiversity: is habitat heterogeneity the key? Trends in Ecology \& Evolution 18:182-188.

Birkhofer, K., T. M. Bezemer, J. Bloem, M. Bonkowski, S. Christensen, D. Dubois, F. Ekelund, A. Fliessbach, L. Gunst, K. Hedlund, P. Mader, J. Mikola, C. Robin, H. Setala, F. Tatin-Froux, W. H. Van der Putten, and S. Scheu. 2008. Long-term organic farming fosters below and aboveground biota: Implications for soil quality, biological control and productivity. Soil Biology and Biochemistry 40:2297-2308.

Dauber, J., T. Purtauf, A. Allspach, J. Frisch, K. Voigtlander, and V. Wolters. 2005. Local Vs. Landscape Controls on Diversity: a Test Using Surface-Dwelling Soil Macroinvertebrates of Differing Mobility. Global Ecology and Biogeography 14:213221.

van Diepeningen, A. D., O. J. de Vos, G. W. Korthals, and A. H. C. van Bruggen. 2006. Effects of organic versus conventional management on chemical and biological parameters in agricultural soils. Applied Soil Ecology 31:120-135.

Fitter, A., C. Gilligan, K. Hollingworth, A. Kleczkowski, R. Twyman, and J. Pitchford. 2005. Biodiversity and ecosystem function in soil. Functional Ecology 19:369-377.

Foley, J. A., R. DeFries, G. P. Asner, C. Barford, G. Bonan, S. R. Carpenter, F. S. Chapin, M. T. Coe, G. C. Daily, H. K. Gibbs, J. H. Helkowski, T. Holloway, E. A. Howard, C. J. Kucharik, C. Monfreda, J. A. Patz, I. C. Prentice, N. Ramankutty, and P. K. Snyder. 2005. Global consequences of land use. Science 309:570-574. 
Gabriel, D., I. Roschewitz, T. Tscharntke, and C. Thies. 2006. Beta diversity at different spatial scales: Plant communities in organic and conventional agriculture. Ecological Applications 16:2011-2021.

Grogan, P. 1998. CO2 flux measurement using soda lime: Correction for water formed during CO2 adsorption. Ecology 79:1467-1468.

van der Heijden, M., R. Bardgett, and N. van Straalen. 2008. The unseen majority: soil microbes as drivers of plant diversity and productivity in terrestrial ecosystems. Ecology Letters 11:296-310.

Hendrickx, F., J. P. Maelfait, W. Van Wingerden, O. Schweiger, M. Speelmans, S. Aviron, I. Augenstein, R. Billeter, D. Bailey, R. Bukacek, F. Burel, T. Diekotter, J. Dirksen, F. Herzog, J. Liira, M. Roubalova, V. Vandomme, and R. Bugter. 2007. How landscape structure, land-use intensity and habitat diversity affect components of total arthropod diversity in agricultural landscapes. Journal of Applied Ecology 44:340-351.

Hole, D. G., A. J. Perkins, J. D. Wilson, I. H. Alexander, F. Grice, and A. D. Evans. 2005. Does organic farming benefit biodiversity? Biological Conservation 122:113-130.

Holzschuh, A., I. Steffan-Dewenter, D. Kleijn, and T. Tscharntke. 2007. Diversity of flowervisiting bees in cereal fields: effects of farming system, landscape composition and regional context. Journal of Applied Ecology 44:41-49.

Jenkinson, D. S., P. C. Brookes, and D. S. Powlson. 2004. Measuring soil microbial biomass. Soil Biology \& Biochemistry 36:5-7.

Jouquet, P., J. Dauber, J. Lagerlof, P. Lavelle, and M. Lepage. 2006. Soil Invertebrates as Ecosystem Engineers: Intended and Accidental Effects on Soil and Feedback Loops. Applied Soil Ecology 32:153-164.

Lukasiewicz, J. 1996. Predation by the beetle Carabus granulatus L (Coleoptera, Carabidae) on soil macrofauna in grassland on drained peats. Pedobiologia 40:364-376. 
Mader, P., A. Fliessbach, D. Dubois, L. Gunst, P. Fried, and U. Niggli. 2002. Soil fertility and biodiversity in organic farming. Science 296:1694-1697.

Marhan, S., E. Kandeler, and S. Scheu. 2007. Phospholipid fatty acid profiles and xylanase activity in particle size fractions of forest soil and casts of Lumbricus terrestris L. (Oligochaeta, Lumbricidae). Applied Soil Ecology 35:412-422.

McLean, M., and D. Parkinson. 1998. Impacts of the epigeic earthworm Dendrobaena octaedra on microfungal community structure in pine forest floor: a mesocosm study. Applied Soil Ecology 8:61-75.

Moore, J., K. McCann, and P. de Ruiter. 2005. Modeling trophic pathways, nutrient cycling, and dynamic stability in soils. Pedobiologia 49:499-510.

Ostman, O., B. Ekbom, J. Bengtsson, and A. C. Weibull. 2001. Landscape complexity and farming practice influence the condition of polyphagous carabid beetles. Ecological Applications 11:480-488.

Pinheiro, J. C., and D. M. Bates. 2000. Mixed-effects Models in S and S-PLUS, 1. edition. Springer, New York.

Purtauf, T., J. Dauber, and V. Wolters. 2005a. The Response of Carabids to Landscape Simplification Differs Between Trophic Groups. Oecologia 142:458-464.

Purtauf, T., I. Roschewitz, J. Dauber, C. Thies, T. Tscharntke, and V. Wolters. 2005b. Landscape Context of Organic and Conventional Farms: Influences on Carabid Beetle Diversity. Agriculture Ecosystems \& Environment 108:165-174.

Roschewitz, I., D. Gabriel, T. Tscharntke, and C. Thies. 2005. The effects of landscape complexity on arable weed species diversity in organic and conventional farming. Journal of Applied Ecology 42:873-882.

Rundlof, M., H. Nilsson, and H. G. Smith. 2008. Interacting effects of farming practice and landscape context on bumblebees. Biological Conservation 141:417-426. 
Rundlof, M., and H. G. Smith. 2006. The effect of organic farming on butterfly diversity depends on landscape context. Journal of Applied Ecology 43:1121-1127.

Rusek, J. 1998. Biodiversity of Collembola and their functional role in the ecosystem. Biodiversity and Conservation 7:1207-1219.

Savin, M., J. Gorres, and J. Amador. 2004. Microbial and microfaunal community dynamics in artificial and Lumbricus terrestris (L.) burrows. Soil Science of America Journal 68:116-124.

Schmidt, M. H., I. Roschewitz, C. Thies, and T. Tscharntke. 2005. Differential effects of landscape and management on diversity and density of ground-dwelling farmland spiders. Journal of Applied Ecology 42:281-287.

Schmidt, M. H., C. Thies, W. Nentwig, and T. Tscharntke. 2008. Contrasting responses of arable spiders to the landscape matrix at different spatial scales. Journal of Biogeography 35:157-166.

Stoate, C., N. D. Boatman, R. J. Borralho, C. R. Carvalho, G. R. de Snoo, and P. Eden. 2001. Ecological impacts of arable intensification in Europe. Journal of Environmental Management 63:337-365.

Swift, M., A. Izac, and M. van Noordwijk. 2004. Biodiversity and ecosystem services in agricultural landscapes - are we asking the right questions? Agriculture Ecosystems \& Environment 104:113-134.

Symondson, W. O. C., D. M. Glen, M. L. Erickson, J. E. Liddell, and C. J. Langdon. 2000. Do earthworms help to sustain the slug predator Pterostichus melanarius (Coleoptera : Carabidae) within crops? Investigations using monoclonal antibodies. Molecular Ecology 9:1279-1292.

Thies, C., I. Steffan-Dewenter, and T. Tscharntke. 2003. Effects of landscape context on herbivory and parasitism at different spatial scales. Oikos 101:18-25. 
Thies, C., and T. Tscharntke. 1999. Landscape structure and biological control in agroecosystems. Science 285:893-895.

Tiunov, A., and S. Scheu. 1999. Microbial respiration, biomass, biovolume and nutrient status in burrow walls of Lumbricus terrestris L. (Lumbricidae). Soil Biology \& Biochemistry 31:2039-2048.

Tiwari, S., and R. Mishra. 1993. Fungal abundance and diversity in earthworm casts and in uningested soil. Biology and Fertility of Soils 16:131-134.

Tscharntke, T., A. M. Klein, A. Kruess, I. Steffan-Dewenter, and C. Thies. 2005a. Landscape perspectives on agricultural intensification and biodiversity - ecosystem service management. Ecology Letters 8:857-874.

Tscharntke, T., T. A. Rand, and F. Bianchi. 2005b. The landscape context of trophic interactions: insect spillover across the crop-noncrop interface. Annales Zoologici Fennici 42:421-432.

Vickery, J., N. Carter, and R. J. Fuller. 2002. The potential value of managed cereal field margins as foraging habitats for farmland birds in the UK. Agriculture Ecosystems \& Environment 89:41-52.

Weibull, A. C., O. Ostman, and A. Granqvist. 2003. Species richness in agroecosystems: the effect of landscape, habitat and farm management. Biodiversity and Conservation 12:1335-1355. 


\section{APPENDIX}

Table S1: Landscape complexity around the sampling sites in 100 and $500 \mathrm{~m}$ radii for each management type pair. org $=$ organical farming, conv $=$ conventional farming

\begin{tabular}{|c|c|c|c|}
\hline \multirow[b]{2}{*}{ Locality } & \multirow[b]{2}{*}{$\begin{array}{c}\text { Managemen } \\
\text { t type }\end{array}$} & \multicolumn{2}{|c|}{ Landscape (\% arable land) } \\
\hline & & $100 \mathrm{~m}$ radius & $500 \mathrm{~m}$ radius \\
\hline Amelsen & conv & 32.50 & 72.73 \\
\hline Amelsen & org & 82.05 & 34.09 \\
\hline Asche & conv & 97.73 & 48.84 \\
\hline Asche & org & 97.96 & 44.00 \\
\hline Bodensee & conv & 71.76 & 30.48 \\
\hline Bodensee & org & 87.12 & 70.83 \\
\hline EbergötzenN & conv & 100.00 & 51.85 \\
\hline EbergötzenN & org & 81.64 & 35.14 \\
\hline EbergötzenS & conv & 97.92 & 37.35 \\
\hline EbergötzenS & org & 100.00 & 70.00 \\
\hline Etzenborn & conv & 100.00 & 35.34 \\
\hline Etzenborn & org & 100.00 & 36.64 \\
\hline Großenrode & conv & 100.00 & 66.67 \\
\hline Großenrode & org & 88.44 & 63.16 \\
\hline Landolfshausen & conv & 100.00 & 42.86 \\
\hline Landolfshausen & org & 53.25 & 25.93 \\
\hline Luethorst & conv & 72.38 & 42.67 \\
\hline Luethorst & org & 79.09 & 41.07 \\
\hline Neuenrode & conv & 85.07 & 24.14 \\
\hline Neuenrode & org & 100.00 & 43.88 \\
\hline Waake & conv & 77.25 & 27.50 \\
\hline Waake & org & 94.10 & 23.75 \\
\hline Wiebrechtshausen & conv & 100.00 & 41.67 \\
\hline Wiebrechtshausen & org & 97.99 & 53.85 \\
\hline
\end{tabular}




\section{Analysis of chemical parameters}

To analyse soil $\mathrm{pH}$ and soil ions $30 \mathrm{~g}$ of wet soil were suspended in $200 \mathrm{ml}$ distilled water, shaken for 45 minutes and centrifuged at 4000RPM for one minute. The supernatant was used for the subsequent analyses.

All analyses were corrected for soil water content. $\mathrm{pH}$ was measured with a pH597-S ProfiLab pHmeter, anions (chloride, phosphate, fluoride, nitrate, nitrite, sulphate) were analysed using dialysis ion exchange chromatography (761 Compact IC, Metrohm, Germany) and cations (calcium, potassium, magnesium, sodium) were analysed by atomic absorption spectroscopy (Perkin-Elmer Aanalyst 300). Soil C/N ratio was determined using dried and milled soil with a Elementar Vario EL-analyser. 
Chapter 4

\section{SPATIAL SCALE PREDICTS THE DISTRIBUTION OF SOIL BIOTA: A COMMUNITY APPROACH}

A. Flohre, M. Rudnick, G. Traser, T. Tscharntke and T. Eggers 


\begin{abstract}
While the biogeography of many vertebrates and invertebrate eukaryotes is well studied, little is known about the biogeography of microorganisms. Although a number of recent papers investigate microbial biogeography on global or continental scales, mechanisms forming microbial communities and thus leading to distinct large-scale spatial patterns are likely to act on very small (i.e. local) scales, too. In addition one wonders whether the same ecological theories, for example dispersal limitation as a driver of large scale biogeography patterns can be applied to soil macro- and microorganisms alike. We used a variance partitioning approach to investigate the relative importance of environmental conditions and spatial distances for soil bacterial, collembolan, carabid beetle and earthworm community composition in agricultural fields and old set-aside fallows, comparing samples from a very small scale of 40 $m$ with samples from a regional scale of up to $13 \mathrm{~km}$.

We found that environmental factors, in particular $\mathrm{pH}$ and soil-nitrate content are good predictors of soil bacterial community composition. In addition, the spatial distribution of our sampling sites also influenced bacterial community composition, indicating a certain degree of provincialism, probably caused by dispersal limitation even on very small scales. However, our analysis also indicates that environmental factors are more important than space. The macroorganism taxa studied in this paper showed differential patterns depending on their average body size. Larger macroorganisms did not show a spatial signal on the local scale. In contrast, their spatial signal is most prominent on the regional scale, while smaller macroorganisms, i.e. collembola, showed a spatial signal on the local but not on the regional scale. Differences between bacteria and macroorganisms are likely to be due to different dispersal modes for these groups. While the macroorganisms disperse actively, bacteria are thought to disperse passively, which could have lead to dispersal limitation in the complex soil environment. However, small active dispersers, i.e. collembola seem to suffer from dispersal limitation on small spatial scales, too. We conclude that microorganism distribution in soil is affected by dispersal limitation, which is also a well known driver of macroorganism biogeography patterns.
\end{abstract}

Key words: bacteria, carabid beetle, collembola, dispersal limitation, earthworm, microbial biogeography, variance partitioning 


\section{INTRODUCTION}

Biogeography is the study of the distribution of organisms in space and time (Martiny et al. 2006). Given that body size of organisms ranges over orders of magnitude from a few micrometers up to the meter-scale suggests that dispersal mechanisms are either very different depending on body size or on an organisms biology or both (Jenkins et al. 2007). Hence, understanding why organisms live where they do and why in this number requires an understanding of the scale at which the main ecological factors operate that result in differential distributions of organisms.

While the biogeography of many vertebrates and invertebrate is well studied (Gaston 2000, Ettema and Wardle 2002), some argue that the dispersal of microbial species is not determined by the classic mechanisms known to act at biogeographical scales such as dispersal limitation due to geographic barriers, fragmented habitat patches, isolation or scarcity of dispersal vectors etc. (Finlay 2002, Fierer and Jackson 2006). However, a number of recent studies have casted considerable doubt on this position (Foissner 2006, Green and Bohannan 2006, Martiny et al. 2006, Langenheder and Ragnarsson 2007). Given the conflicting evidence available the question is as to whether the same ecological theories apply to macro- and microorganisms alike (Martiny et al. 2006, Horner-Devine et al. 2007). Evidence that this might be the case comes for example from studies on the species-area relationship of microbial diversity (Green et al. 2004, Horner-Devine et al. 2004, Bell et al. 2005, Noguez et al. 2005), a pattern well studied in the macroecology of plants and animals alike (see for example Crawley and Harral 2001, Kreft et al. 2008).

Studying the scales at which microbial communities are influenced by spatial and environmental factors might help unraveling the mechanisms underlying large-scale biogeographic processes. Most studies published on microbial biogeography investigate distributions on continental or global scales (Whitaker et al. 2003, Fierer and Jackson 2006, Fierer et al. 2009), regional scales (Fierer et al. 2007, Langenheder and Ragnarsson 2007) or both (Van der Gucht et al. 2007). But mechanisms forming microbial communities and thus leading to distinct large-scale spatial patterns such as effects of environmental conditions and physical habitat properties (i.e. soil texture, water content etc.) or dispersal limitation are likely to act on very small (i.e. local) scales, too (Bardgett 2005). A systematic approach is needed investigating the distribution of microorganisms at various spatial scales in order to understand which mechanisms operating on small scales might influence community composition of microorganisms at larger scales (Martiny et al. 2006). In addition, it is 
imperative to distinguish between contemporary environmental factors and historical contingencies possibly influencing the distribution of microorganisms. In case of nonubiquitous dispersal, even if the current environmental conditions are equal, differing environmental history would lead to dissimilar communities across space, with similarity decreasing with geographic distance (Tuomisto et al. 2003, Soininen et al. 2007). Hence, to study the historic effects of local environmental factors and to examine biogeographic patterns in distributions, studies need to consider both spatial (i.e. variation in community composition attributed to spatial separation) and current environmental (i.e. variation in community composition attributed to environmental conditions over space) effects (Cottenie 2005, Van der Gucht et al. 2007).

The variance partitioning approach is a good tool to study the relative importance of these variables (Borcard et al. 1992, Peres-Neto et al. 2006). The explained variance in community composition is divided into variance explained only by either spatial (geographic distance) or environmental and by both variables together. If all important environmental variables are measured, variance explained by spatial factors hints to provincialism and hence to biogeography.

In this study we sampled four taxonomic groups differing both in body size and life strategies, thus creating contrasts in dispersal mode due to these two factors (Jenkins et al. 2007). The studied organisms were namely bacteria with a body diameter of a few micrometers and a largely passive dispersal mode (Martiny et al. 2006), (Bardgett 2005), collembolans (body length $0.3-3 \mathrm{~mm}$ ), carabid beetles (body length $10.55 \pm 7.31 \mathrm{~mm}$ ) and earthworms (body length $80.93 \pm 12.63 \mathrm{~mm}$ ) all of which are active dispersers (Gutierrez et al. 1997, Sims and Gerard 1999, Thomas et al. 2006). We compared community patterns of these organism groups on a local $(0,04 \mathrm{~km}$ distance) and on a regional scale $(0,17-13 \mathrm{~km}$ distance) using a paired-plot design with wheat fields and fallows.

In using this design we asked the following questions:

(1) Do bacteria communities exhibit differential patterns on the local and regional scale?

(2) Do macroorganism communities also exhibit differential patterns on these scales and do the patterns of bacteria and macroorganisms differ?

(3) Are there differences in community patterns between organisms of different body size and dispersal mode?

(4) How much of the variation in community composition can be explained by environmental and spatial factors, respectively? 


\section{MATERIAL AND METHODS}

\section{Study region and sampling design}

Samples were taken in September 2008 from five pairs of agricultural winter-wheat fields and fallows in the region around the city Göttingen (Lower Saxony, Germany). The distance between the pairs ranged from $0,17-13,4 \mathrm{~km}$ with a mean of 5,4 $\mathrm{km} \pm 1,8$ (SE). After the wheat harvest and two weeks prior to sampling fields were ploughed to $20 \mathrm{~cm}$ depth. Before the winter wheat all fields were planted with either wheat or barley. Set asides were long-term set asides (five years minimum).

All sampling sites had similar soil types (Cambisols). For each plot pair samples were taken in one, five, ten and twenty meters distance to the field/fallow boundary. The location of these sampling points in each pair entered the variance partitioning procedure as the spatial variable "local", while the location of the agricultural field/set-aside pair entered as the spatial variable "regional".

Carabid species were trapped using pitfalls (diameter $9 \mathrm{~cm}$ ), opened for one week between 15 and 22 September 2008. At each sampling point four pitfall traps on a four meter transect parallel to the field/set-aside boundary were used. Individuals of all four pitfall traps were pooled to estimate species richness of one sampling point. The trapping fluid was watery ethylene- glycol solution $(1 / 1 \mathrm{v} / \mathrm{v})$. Carabids were stored in $70 \%$ ethanol, identified down to species level and counted. In addition, the average body size of determined specimens was taken from a standard identification key (Freude et al. 1976).

$380 \mathrm{~cm}^{3}$ soil cores were taken from each sampling point and springtails (Insecta:Collembola) were extracted using MacFadyen's high gradient extraction and identified to species level. The protocol was as following: start at $17.5^{\circ} \mathrm{C}$, increasing temperature in $2.5^{\circ} \mathrm{C}$ steps per day for five days, increasing temperature in $5^{\circ} \mathrm{C}$ steps per day for six days.

On each sampling point a soil monolith $(1 \mathrm{~m} * 1 \mathrm{~m} * 25 \mathrm{~cm})$ was taken and earthworms were hand sorted, stored in $70 \%$ ethanol and identified to species level. Body length was taken from a standard identification key (Brohmer et al. 2000).

In addition four soil samples from each sampling site were pooled and stored for analysis of chemical parameters and bacterial community composition in the lab. 
To analyse soil $\mathrm{pH}$ and soil ions $30 \mathrm{~g}$ of wet soil were suspended in $200 \mathrm{ml}$ distilled water, shaken for 45 minutes and centrifuged at 4000 RPM for one minute. The supernatant was used for the subsequent analyses.

The $\mathrm{pH}$ was measured with a pH597-S ProfiLab pHmeter, anions (chloride, phosphate, fluoride, nitrate, nitrite, sulphate) were analysed using dialysis ion exchange chromatography (761 Compact IC, Metrohm, Germany; Column Metrosep A-Supp 4/250, flow rate 1,0 ml/L , eluent natrium narbonate, natriumhydrogencarbonate $1,7 \mathrm{mmol} / 1,8 \mathrm{mmol}$ ) and cations (calcium, potassium, magnesium, sodium) were analysed by atomic absorption spectroscopy (Perkin-Elmer Aanalyst 300). Soil C/N ratio was determined using dried and milled soil with an Elementar Vario EL-analyser. Both cation and anion analysis results were expressed in $\mathrm{mg}$ per kg dry soil.

\section{Bacterial community composition (BCC)}

BCC was determined using the relative abundance of taxon specific 16s ribosomal DNA (rDNA). Measures were obtained using quantitative real-time polymerase chain reaction, qPCR, (Fierer et al. 2005, Ginzinger 2002). Microbial DNA was extracted from the soil samples using the MOBIO Ultra Clean Soil DNA Extraction kit (MOBIO Laboratories, Carlsbad, CA, USA).

Real-time PCR was performed for seven dominant bacteria groups found in soils following a protocol established by Fierer et al. (2005) and Fierer and Jackson (2006) (Table 1). Group specific annealing temperatures as proposed by Fierer et al. (2005) were tested with conventional PCR and found to be appropriate. qPCR assays were conducted in 48-well plates on an ABI StepOne Real-Time PCR System (Applied Biosystems). Each $20 \mu 1$ reaction contained the following: $10 \mu \mathrm{l}$ DyNamoFlash SYBR Green qPCR Kit (Biozym), $0.6 \mu 1$ of each primer (10 $\mu \mathrm{M}$ stock solution, Eurogentec), $0.12 \mu 1$ ROX dye (Biozym), $5 \mu 1$ template ( $\sim 5 \mathrm{ng} / \mu \mathrm{l}$ depending on the environmental sample), $3.5 \mu \mathrm{l}$ bovine serum albumin $(20 \mathrm{mg} / \mathrm{ml}$ stock solution) and $0.4 \mu 1 \mathrm{MgCl}_{2}$ (25mM stock solution). Reaction volumes were adjusted to $20 \mu \mathrm{l}$ using sterile water. PCR conditions started with a 7 minutes initial denaturation at $95^{\circ} \mathrm{C}$ followed by 40 cycles at $95{ }^{\circ} \mathrm{C}$ for 15 seconds followed by the group specific annealing temperature for $15 \mathrm{sec}$ and elongation phase at $72{ }^{\circ} \mathrm{C}$ for $30 \mathrm{sec}$. Each assay was done in triplicate and mean values were used for further analysis. Group specific template concentrations were determined using a five point 1:2 dilution curve for each group. For all assays a linear relationship between the log of the DNA copy number and the calculated 
threshold value was found $\left(\mathrm{R}^{2}>0.95\right.$ for all assays; data not shown). In addition melting curve analysis was done to confirm that fluorescence signals originated from specific PCR products.

Table 1: Description of the group specific primers used in qPCR assays following Fierer et al. (2005)

\begin{tabular}{lll}
\hline \multicolumn{1}{c}{ Target group } & \multicolumn{1}{c}{ Primer sequence (5'-3') } & Primer name \\
\hline Bacteria & ACT CCT ACG GGA GGC AGC AG & Eub338 \\
Bacteria & ATT ACC GCG GCT GCT GG & Eub518 \\
$\alpha-$ & TCT ACG RAT TTC ACC YCT AC & Alf685 \\
$\beta$-Proteobacteria & TCA CTG CTA CAC GYG & Bet680 \\
Actinobacteria & CGC GGC CTA TCA GCT TGT TG & Actino235 \\
Firmicutes & GCA GTA GGG AAT CTT CCG & Lgc353 \\
Bacteroidetes & GTA CTG AGA CAC GGA CCA & Cfb319 \\
Acidobacteria & GAT CCT GGC TCA GAA TC & Acid31 \\
\hline
\end{tabular}

\section{Statistical analysis}

We used a variance partitioning procedure based on redundancy analysis (RDA) to determine the relative importance of environmental (E) and spatial (S) factors (Borcard et al. 1992, Peres-Neto et al. 2006). Variance component estimates were adjusted according to Peres-Neto et al. (2006). The total variation in community composition of bacteria, earthworms, carabids and collembolan was split into spatial variation [S], divided further into spatial variation on the local (distance) and regional (locality) scale respectively; environmental variation [E]; total explained variation $[\mathrm{E}+\mathrm{S}]$; the fraction of variation explained by spatial factors independent of environmental gradients $[\mathrm{S} \mid \mathrm{E}]$; the fraction of variation explained by environmental factors independent of spatial factors $[\mathrm{E} \mid \mathrm{S}]$; the explained variation shared by environmental and spatial factors (i.e. environmental gradients which are correlated with spatial structures) $[\mathrm{E} \cap \mathrm{S}]$ and finally the unexplained variation $1-[\mathrm{E}+\mathrm{S}]$.

Community composition data were square-root transformed to normalize skewed density data and used as response matrices. For each group, only significant environmental factors were used in the subsequent analysis (table 2). Significance was determined using RDAs and the envfit function in the Vegan package in R (Oksanen 2009). The function fits environmental vectors or factors onto an ordination. It finds directions in the ordination in which the environmental vectors change the most and where they have maximal correlations with the ordination. Significance of the fit is then obtained by using a Monte-Carlo-permutation test with 1000 permutation, testing the actual model against a null model of a random distribution. All environmental data matrices were standardized and centered prior to analysis (mean 0 ; stdev 1). Afterwards a variance partitioning was applied using the varpart function in $\mathrm{R}$. 
Significance of different fractions was tested with a permutation test of simple and partial RDA with a maximum 999 permutations. All analyses were done in R 2.10 (R Development Core Team 2009) and with the Vegan 1.15-4 package for R (Oksanen 2009). 
Table 2. Environmental factor significance in explaining community composition; (.) $\mathrm{P}<0.01, * \mathrm{P}<0.05 ; * * \mathrm{P}<0.01 ; * * * \mathrm{P}<0.001$

\begin{tabular}{|c|c|c|c|c|c|c|c|c|c|c|c|c|c|c|c|}
\hline Taxa & Fluoride[mg/l] & chloride[mg/l] & nitrite[mg/l] & nitrate[mg/l] & phosphate[mg/l] & sulphate[mg/l] & $\mathrm{Na}[\mathrm{mg} / \mathrm{l}]$ & $\mathrm{Mg}[\mathrm{mg} / \mathrm{l}]$ & $\mathrm{K}[\mathrm{mg} / \mathrm{l}]$ & $\mathrm{Ca}[\mathrm{mg} / \mathrm{l}]$ & $\mathrm{pH}$ & $\begin{array}{l}\text { water } \\
\text { content }\end{array}$ & $\% \mathrm{~N}$ & $\% \mathrm{C}$ & CNRatio \\
\hline Carabidae & & $* *$ & $* *$ & $*$ & $*$ & & & & & & & $* * *$ & & & $* *$ \\
\hline Bacteria & & & * & $* *$ & & & & & & $* * *$ & $* * *$ & $*$ & & & \\
\hline Earthworms & & & & & & & & & & $*$ & $* *$ & & & & \\
\hline Collembola & & & $*$ & $*$ & $* *$ & & & & & & (.) & $* *$ & $* *$ & $* *$ & \\
\hline
\end{tabular}

Notes: Na, sodium; Mg magnesium; K, potassium; Ca, calcium; water content, soil water content; CNRatio, carbon-nitrogen ratio. 


\section{RESULTS}

Variance partitioning revealed that the measured environmental and spatial variables together explained between 30 and $70 \%$ of the variation in community composition (Table 3 ).

On the local scale, spatial variables alone explained 8.1 and $7.1 \%$ of variation for bacteria and collembolans, respectively (Figure 1). On the regional scale, a significant portion of the total variation was explained by space for carabidae, bacteria and earthworms, whereas no effect of space was found for the abundance distribution of collembola (Figure 1). Changing environmental conditions within local and regional scale, i.e. different environmental conditions across space on the local or regional scale, could explain large parts of the variation for all groups except earthworm community composition on the local scale.

The significance of environmental variables measured in agricultural soils for community composition of carabidae, bacteria, earthworms and collembola are summarized in Table 2. Soil water and nitrate content and $\mathrm{pH}$ were the most important predictors for soil biota communities.

Table 3: Partitioning of the explained variance for the three explanatory data sets; local space alone [a], regional space alone $[\mathrm{b}]$, environment alone $[\mathrm{c}]$, local space and environment $[\mathrm{a}+\mathrm{c}]$, regional space and environment $[\mathrm{b}+\mathrm{c}]$ and unexplained or residual variation [d]. The adjusted $\mathrm{R}^{2}$ is given. Note that negative estimates of explained variation indicate large variability in the data. Only the main factors [a], [b] and [c] are statistically testable. (.) $\mathrm{P}<0.1,{ }^{*} \mathrm{P}<0.05 ; * * \mathrm{P}<0.01 ; * * * \mathrm{P}<0.001$

\begin{tabular}{ccccccccc}
\hline & \multicolumn{7}{c}{ Adjusted $^{2}$} \\
\cline { 2 - 8 } Taxa & {$[\mathrm{a}]$} & {$[\mathrm{b}]$} & {$[\mathrm{c}]$} & {$[\mathrm{a}+\mathrm{b}]$} & {$[\mathrm{a}+\mathrm{c}]$} & {$[\mathrm{b}+\mathrm{c}]$} & {$[\mathrm{a}+\mathrm{b}+\mathrm{c}]$} & {$[\mathrm{d}]$} \\
\hline Bacteria & 8.1 & $16.3^{*}$ & $6.6()$. & 0 & 14.7 & 31.4 & -9.6 & 33 \\
& $*$ & $*$ & & & & & & \\
Collembola & 7.1 & & 12.4 & 1.7 & 6.3 & 5.9 & -4.6 & 69.6 \\
& $*$ & & $*$ & & & & & \\
Carabids & -2.2 & $21.6^{*}$ & $9.3^{*}$ & -3.6 & 19.8 & 8.9 & -3 & 49.3 \\
Earthworm & & $*$ & & & & & & \\
$\mathrm{~s}$ & -4.2 & $*$ & 0 & -4.2 & 3.4 & 14.1 & -2.9 & 68.8 \\
\hline
\end{tabular}




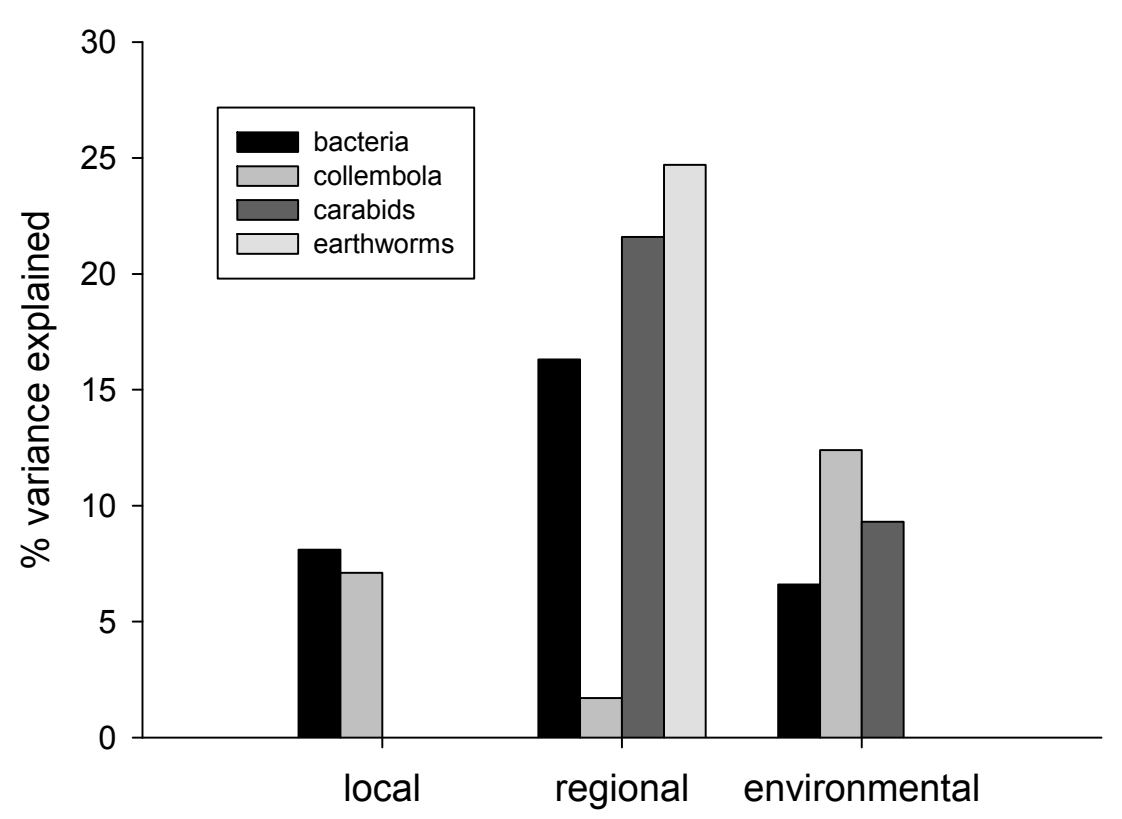

Figure 1: Comparison of variance explained purely by local and regional spatial scale and purely by environmental factors. Results are shown for bacteria, collembola, carabids and earthworms. Negative values were set to zero, see text for explanation.

\section{DISCUSSION}

We found that both spatial and environmental factors influenced the community composition of our study organisms. While local space mainly influenced bacterial and collembola communities, regional space had a greater impact on all studied organism groups except for the collembolans. The environment and differences in environmental conditions across space on the local and regional scale were important in forming community composition for all groups.

Here we show that soil bacteria had a differential distribution even on very small scales, which means that even $40 \mathrm{~m}$ apart bacterial community composition (BCC) differed independent of environmental conditions with $8 \%$ of the total variation explained by spatial factors alone. On a regional scale, 16 percent of the total variation was atributable to spatial factors alone, excluding local scale effects. Environmental factors could explain 7 percent of 
the BCC variation alone. In addition changing environmental conditions between local and regional sampling points explained another 46 percent of the total variability.

While we sampled all those environmental factors that are known to influence BCC, namely pH and soil C/N (Fierer and Jackson 2006, Fierer et al. 2007, 2009, Lauber et al. 2009), we did not sample biological parameters, e.g. protists and other predators. Given the spatial dynamic of these groups and their importance for BCC (e.g. Bonkowski 2004) they might have explained additional variation that currently is included within the spatial structure of our model. Changes in these biological parameters along a spatial gradient might be able to feed back on to the BCC (see for example grazing in aquatic environments, (Hahn and Hofle 2001, Sherr and Sherr 2002).

Although the classical view on microbial biogeography assumes unlimited dispersal of bacteria ("everything is everywhere, the environment selects" Baas-Becking 1934), dispersal per se has seldom been studied except for the bacterial dispersal by air that has drawn considerable attention (Kellogg and Griffin 2006, Brodie et al. 2007, Pearce et al. 2009, Jones and McMahon 2009). If bacteria are really ubiquitous due to their high dispersal rates, bacterial community composition should be solely driven by environmental conditions. In contrast to the classical view, our data reveal that the spatial structure appears to play a considerable role for BCC even on small scales. This effect might be explained by historical events such as past differences in environmental conditions between sites combined with dispersal limitation (see e.g. Martiny et al. 2006, Van der Gucht et al. 2007). In soil, dispersal of bacteria could be realized through active movement of organisms or passively trough soilwater movements, biological vectors like earthworms (Daane et al. 1997) or agricultural practices like ploughing or transfer of soils. Active dispersal of bacteria can be neglected in terms of distance (Martiny et al. 2006) and passive dispersal of microbes seems to be limited, as indicated by the spatial signal in our model. However, the spatial scale on which dispersal limitation acts may depend on bacterial species identity. For example, in two intercontinental studies on hot spring microbial assemblages, communities were separated by distance and not correlated to environmental variables (Papke et al. 2003, Whitaker et al. 2003).

Out of the macroorganisms studied, only collembola showed a biogeographical signal, i.e. a part of the variance in community composition solely explained by space, on the local scale. However, changes in environmental conditions between field and fallow explained 19.8 percent of the total variation for carabids. This means that no differences in community composition were apparent after accounting for responses to different environmental conditions between fields and fallows on the local scale, thus suggesting an effective spatial 
niche separation of species along an environmental gradient. This conforms to strong species sorting as introduced by the metacommunity concept (Leibold et al. 2004). On the regional scale all studied macroorganism groups except collembola showed a biogeographical distribution with 22 and 25 percent of the variation explained by spatial factors alone for carabids and earthworms respectively. Such a spatial distribution is strong evidence for provincialism, where differences in community composition are rather due to past events than present environmental conditions, a well studied mechanism known to act in macroorganism biogeography (Whitaker et al. 2003, Vyverman et al. 2007).

Another 9 and 14 percent were explained by changing environmental conditions betweens sites, suggesting a certain degree of species sorting along an environmental gradient for these two groups as well. Collembola community composition on the other hand was mainly determined by both spatial factors on the local scale and environmental factors independent of space. This suggests that collembola are limited in their dispersal ability making them prone to a stronger regulation by environmental factors. This is supported by evidence presented in a recent review on dispersal distance and body-size, showing that dispersal distance of active dispersers increases with body-size (Jenkins et al. 2007).

Bacteria showed a high degree of species sorting (33 percent of variation explained by changing environmental conditions between sites) together with provincialism (16 percent variation explained by spatial factors alone) on the regional scale. Our results fit into a vivid debate about microbial biogeography on local scales in ponds, lakes or soils. While most microbial biogeography studies were done either in lakes, streams or ponds (Fierer et al. 2007, Langenheder and Ragnarsson 2007, Van der Gucht et al. 2007, Jones and McMahon 2009), only a few studies addressed soil communities on predominantly large-scales (Fierer and Jackson 2006, Martiny et al. 2006, Fierer et al. 2009) with data on small scale spatial effects on $\mathrm{BCC}$ independent from environmental conditions largely missing. Whereas most authors find species sorting to be the most important driver for $\mathrm{BCC}$ on larger scales, spatial segregation is reported several times for ponds and lakes (Langenheder and Ragnarsson 2007, Van der Gucht et al. 2007). We report the first results showing bacterial spatial segregation independent of environmental conditions on small scales in soil. Unfortunately it is difficult to quantitatively compare studies on this subject as studies were done in various degrees of taxonomical resolution and with different statistical tools; hence, there is a need to standardize the sampling and methods.

Differences between micro- and macroorganisms are most probably due to different dispersal modes. The studied macroorganisms disperse actively (Gutierrez and Menendez 1997, Sims 
and Gerard 1999, Thomas et al. 2006) which could have led to an effective species sorting along environmental gradients on a local scale. However, as mentioned before, dispersal distance of active dispersers is increases with body size (Jenkins et al. 2007), which could have led to dispersal limitation for small active dispersers like collembola even on the local scale. In contrast, the prime mode of dispersal for bacteria is most probably passive dispersal with water, wind and animal vectors, which could lead to dispersal limitation and provincialism even on small scales.

In conclusion, we found that environment is an important driver of soil BCC. However, the spatial distribution of our sampling sites is also reflected in BCC, hinting to a certain degree of provincialism even on very small scales. In relative terms our analysis also indicates that environmental factors such as soil $\mathrm{pH}$, calcium and nitrate content are more important than space. The macroorganism taxa studied in this paper showed differential patterns depending on their average body size. The larger macroorganisms did not show any spatial signals on the local scales. In contrast, their spatial signal is most prominent on the regional scale, while smaller macroorganisms, i.e. collembola, showed a spatial signal on the local but not on the regional scale. Differences between the micro- and macroorganisms studied are likely to be due to their differental dispersal modes. While the macroorganisms disperse actively, bacteria are thought to disperse passively, which might have lead to dispersal limitation in the complex soil environments studied. However, even within the macro biota small active dispersers, such as collembola seem to suffer from dispersal limitation, too. In contrast to conventional wisdom, we conclude that the distribution and abundance of microorganism in soils is affected by dispersal limitation, a well known driver of macroorganism biogeography patterns.

\section{ACKNOWLEDGMENTS}

We thank the farmers that allowed us to work on their fields. We also thank the Eurodiversity programme AGRIPOPES and the biolog programme (BIOPLEX http://www.unigiessen.de/bioplex) of the Federal Ministry of Education and Science (BMBF) for funding. 


\section{REFERENCES}

Baas-Becking, L. 1934. Geobiologie of Inleiding Tot de Milieukunde. Van Stockkum \& Zoon, The Hague.

Bardgett, R. D. 2005. The Biology of Soil: A community and ecosystem approach. Oxford University Press, Oxford.

Bell, T., D. Ager, J. I. Song, J. A. Newman, I. P. Thompson, A. K. Lilley, and C. J. van der Gast. 2005. Larger islands house more bacterial taxa. Science 308:1884-1884.

Bonkowski, M. 2004. Protozoa and plant growth: the microbial loop in soil revisited. New Phytologist 162:617-631.

Borcard, D., P. Legendre, and P. Drapeau. 1992. Partialling out the Spatial Component of Ecological Variation. Ecology 73:1045-1055.

Brodie, E. L., T. Z. DeSantis, J. P. M. Parker, I. X. Zubietta, Y. M. Piceno, and G. L. Andersen. 2007. Urban aerosols harbor diverse and dynamic bacterial populations. Proceedings of the National Academy of Sciences of the United States of America 104:299-304.

Brohmer, P., M. Schaefer, H. Bohlken, H. Reichstein, and K. Sattler. 2000. Brohmer Fauna von Deutschland. Ein Bestimmungsbuch unserer heimischen Tierwelt, 19. edition. Quelle + Meyer.

Cottenie, K. 2005. Integrating environmental and spatial processes in ecological community dynamics. Ecology Letters 8:1175-1182.

Crawley, M. J., and J. E. Harral. 2001. Scale dependence in plant biodiversity. Science 291:864-868.

Daane, L. L., J. A. E. Molina, and M. J. Sadowsky. 1997. Plasmid transfer between spatially 
separated donor and recipient bacteria in earthworm-containing soil microcosms. Applied and Environmental Microbiology 63:679-686.

Ettema, C., and D. Wardle. 2002. Spatial soil ecology. Trends in Ecology \& Evolution 17:177-183.

Fierer, N., J. A. Jackson, R. Vilgalys, and R. B. Jackson. 2005. Assessment of soil microbial community structure by use of taxon-specific quantitative PCR assays. Applied and Environmental Microbiology 71:4117-4120.

Fierer, N., and R. B. Jackson. 2006. The diversity and biogeography of soil bacterial communities. Proceedings of the National Academy of Science of the United States of America 103:626-631.

Fierer, N., J. L. Morse, S. T. Berthrong, E. S. Bernhardt, and R. B. Jackson. 2007. Environmental controls on the landscape-scale biogeography of stream bacterial communities. Ecology 88:2162-2173.

Fierer, N., M. S. Strickland, D. Liptzin, M. A. Bradford, and C. C. Cleveland. 2009. Global patterns in belowground communities. Ecology Letters 12:1238-1249.

Finlay, B. J. 2002. Global dispersal of free-living microbial eukaryote species. Science 296:1061-1063.

Foissner, W. 2006. Biogeography and dispersal of micro-organisms: A review emphasizing protists. Acta Protozoologica 45:111-136.

Freude, H., K. W. Harde, and G. A. Lohse. 1976. Die Käfer Mitteleuropas. Goecke and Evers, Krefeld.

Gaston, K. J. 2000. Global patterns in biodiversity. Nature 405:220-227.

Ginzinger, D. G. 2002. Gene quantification using real-time quantitative PCR: An emerging technology hits the mainstream. Experimental Hematology 30:503-512. 
Green, J., and B. J. M. Bohannan. 2006. Spatial scaling of microbial biodiversity. Trends in Ecology and Evolution 21:501-507.

Green, J. L., A. J. Holmes, M. Westoby, I. Oliver, D. Briscoe, M. Dangerfield, M. Gillings, and A. J. Beattie. 2004. Spatial scaling of microbial eukaryote diversity. Nature 432:747-750.

Gutierrez, D., and R. Menendez. 1997. Patterns in the distribution, abundance and body size of carabid beetles (Coleoptera : Caraboidea) in relation to dispersal ability. Journal of Biogeography 24:903-914.

Hahn, M., and M. Hofle. 2001. Grazing of protozoa and its effect on populations of aquatic bacteria. Fems Microbiology Ecology 35:113-121.

Horner-Devine, M. C., M. Lage, J. B. Hughes, and B. J. M. Bohannan. 2004. A taxa-area relationship for bacteria. Nature 432:750-753.

Horner-Devine, M. C., J. M. Silver, M. A. Leibold, B. J. M. Bohannan, R. K. Colwell, J. A. Fuhrman, J. L. Green, C. R. Kuske, J. B. H. Martiny, G. Muyzer, L. Ovreas, A. L. Reysenbach, and V. H. Smith. 2007. A comparison of taxon co-occurrence patterns for macro- and microorganisms. Ecology 88:1345-1353.

Jenkins, D. G., C. R. Brescacin, C. V. Duxbury, J. A. Elliott, J. A. Evans, K. R. Grablow, M. Hillegass, B. N. LyonO, G. A. Metzger, M. L. Olandese, D. Pepe, G. A. Silvers, H. N. Suresch, T. N. Thompson, C. M. Trexler, G. E. Williams, N. C. Williams, and S. E. Williams. 2007. Does size matter for dispersal distance? Global Ecology and Biogeography 16:415-425.

Jones, S. E., and K. D. McMahon. 2009. Species-sorting may explain an apparent minimal effect of immigration on freshwater bacterial community dynamics. Environmental Microbiology 11:905-913.

Kellogg, C. A., and D. W. Griffin. 2006. Aerobiology and the global transport of desert dust. 
Trends in Ecology \& Evolution 21:638-644.

Kreft, H., W. Jetz, J. Mutke, G. Kier, and W. Barthlott. 2008. Global diversity of island floras from a macroecological perspective. Ecology Letters 11:116-127.

Langenheder, S., and H. Ragnarsson. 2007. The role of environmental and spatial factors for the composition of aquatic bacterial communities. Ecology 88:2154-2161.

Lauber, C. L., M. Hamady, R. Knight, and N. Fierer. 2009. Pyrosequencing-Based Assessment of Soil $\mathrm{pH}$ as a Predictor of Soil Bacterial Community Structure at the Continental Scale. Applied and Environmental Microbiology 75:5111-5120.

Leibold, M. A., M. Holyoak, N. Mouquet, P. Amarasekare, J. M. Chase, M. F. Hoopes, R. D. Holt, J. B. Shurin, R. Law, D. Tilman, M. Loreau, and A. Gonzalez. 2004. The metacommunity concept: a framework for multi-scale community ecology. Ecology Letters 7:601-613.

Martiny, J. B. H., B. J. M. Bohannan, J. H. Brown, R. K. Colwell, J. A. Fuhrman, J. L. Green, M. C. Horner-Devine, M. Kane, J. A. Krumins, C. R. Kuske, P. J. Morin, S. Naeem, L. Ovreas, A. L. Reysenbach, V. H. Smith, and J. T. Staley. 2006. Microbial biogeography: putting microorganisms on the map. Nature Reviews Microbiology 4:102-112.

Noguez, A. M., H. T. Arita, A. E. Escalante, L. J. Forney, F. Garcia-Oliva, and V. Souza. 2005. Microbial macroecology: highly structured prokaryotic soil assemblages in a tropical deciduous forest. Global Ecology and Biogeography 14:241-248.

Oksanen, J. 2009. Vegan: r Functions for Vegetation Ecologists. Available at http://cc.oulu.fi/ jarioksa/softhelp/vegan.html.

Papke, R. T., N. B. Ramsing, M. M. Bateson, and D. M. Ward. 2003. Geographical isolation in hot spring cyanobacteria. Environmental Microbiology 5:650-659.

Pearce, D. A., P. D. Bridge, K. A. Hughes, B. Sattler, R. Psenner, and N. J. Russell. 2009. 
Microorganisms in the atmosphere over Antarctica. Fems Microbiology Ecology 69:143-157.

Peres-Neto, P. R., P. Legendre, S. Dray, and D. Borcard. 2006. Variation partitioning of species data matrices: Estimation and comparison of fractions. Ecology 87:2614-2625.

R Development Core Team. 2009. R: A Language and Environment for Statistical Computing. Available at: http://www.R-project.org. Foundation for Statistical Computing, Vienna.

Sherr, E., and B. Sherr. 2002. Significance of predation by protists in aquatic microbial food webs. Antonie van Leeuwenhoek International Journal of General and Molecular Microbiology 81:293-308.

Sims, R. W., and B. M. Gerard. 1999. Earthworms. Brill Archive, Bath.

Soininen, J., R. McDonald, and H. Hillebrand. 2007. The distance decay of similarity in ecological communities. Ecography 30:3-12.

Thomas, C. F. G., N. J. Brown, and D. A. Kendall. 2006. Carabid movement and vegetation density: Implications for interpreting pitfall trap data from split-field trials. Agriculture Ecosystems \& Environment 113:51-61.

Tuomisto, H., K. Ruokolainen, and M. Yli-Halla. 2003. Dispersal, environment, and floristic variation of western Amazonian forests. Science 299:241-244.

Van der Gucht, K., K. Cottenie, K. Muylaert, N. Vloemans, S. Cousin, S. Declerck, E. Jeppesen, J. M. Conde-Porcuna, K. Schwenk, G. Zwart, H. Degans, W. Vyverman, and L. De Meester. 2007. The power of species sorting: Local factors drive bacterial community composition over a wide range of spatial scales. Proceedings of the National Academy of Sciences of the United States of America 104:20404-20409.

Vyverman, W., E. Verleyen, K. Sabbe, K. Vanhoutte, M. Sterken, D. A. Hodgson, D. G. Mann, S. Juggins, B. V. De Vijver, V. Jones, R. Flower, D. Roberts, V. A. Chepurnov, 
C. Kilroy, P. Vanormelingen, and A. De Wever. 2007. Historical processes constrain patterns in global diatom diversity. Ecology 88:1924-1931.

Whitaker, R. J., D. W. Grogan, and J. W. Taylor. 2003. Geographic barriers isolate endemic populations of hyperthermophilic archaea. Science 301:976-978. 
ChAPTER 5

SYNTHESIS 
In our study, $\beta$-diversity and hence species turnover between fields, farms and regions accounted for the major part of the total diversity, an effect consistent over nine European regions and multiple scales. Agricultural intensification decreased species richness of plants and birds on all scales, i.e. local agricultural intensification did not only negatively affect the local diversity on the field, but was also related to reduced species turnover between fields, farms and regions. In contrast, carabid beetles were not affected by agricultural intensification, possibly due to a relatively high tolerance to pesticides and a high immigration from surrounding field margins and semi-natural habitats. However, agricultural intensification did not cause a higher relative contribution of $\alpha$ - than $\beta$ diversity to total diversity, which would have indicated a community homogenizing effect of agricultural intensification. Relative contributions of $\beta$-diversity to total diversity across all scales were species group specific, highlighting the need to consider traits such as species mobility when planning agri-environmental schemes. So on the one hand agricultural intensification had severe negative effects on aboveground biota.

Soil organisms, on the other hand, were not as pronouncedly affected as aboveground biota. Organical farming as a countermeasure to prevent biodiversity loss under conventional farming did not lead to higher species richness of soil organisms. Only collembola abundance was slightly increased as a result of organic farming, while soil respiration, a proxy for microbial activity, increased through conventional farming. However, the landscape context (i.e. the amount of arable land around the fields) played a significant role. Organic management increased earthworm species richness and microbial biomass, but only in simple landscapes, whereas it decreased species richness and microbial biomass in complex landscapes. Effects of earthworm species richness and microbial biomass might be related, as earthworms facilitate fungal and bacterial abundance and diversity in soil. Together with losses of predator abundance and diversity in simplified landscapes, effects of agrochemical inputs, which reduced predator abundance in conventional managed fields appeared to allow the observed positive relationship of earthworm species richness and landscape complexity in organically managed fields.

Environment is an important driver of soil bacterial community composition. However, the spatial distribution of small-scale sampling sites is also reflected in bacterial community composition, hinting to a certain degree of provincialism even on very small scales. In 
relative terms our analysis also indicates that environmental factors such as soil $\mathrm{pH}$, calcium and nitrate content are more important than spatial distance. Collembola, carabid beetles and earthworms showed differential patterns in relation to their average body size. The larger macroorganisms did not show any spatial signal on the local scales. In contrast, their spatial signal is most prominent on the regional scale, and only the small collembola showed a spatial signal on the local, not the regional scale. Differences between bacteria and carabids or earthworms as larger macroorganisms are likely to be due to different dispersal modes for bacteria and macroorganisms in soil. While the macroorganisms disperse actively, bacteria are presumed to disperse passively, which could have lead to dispersal limitation in the complex soil environment. However, small active dispersers such as collembola seem to suffer from dispersal limitation, too.

Overall we conclude that agricultural intensification had negative effects on most of the studied aboveground taxa, with detrimental effects acting over multiple spatial scales. In contrast, organic farming appears to be more efficient in conserving aboveground than belowground diversity, which could be due to the enormous functional redundancy of the belowground community and therefore high resilience and resistance to anthropogenic disturbances. However, landscape context played a significant role in interaction with local management, emphasizing the importance of agri-environmental schemes designed for local and regional scales alike. The relative importance of environmental and spatial factors for soil communities appeared to depend on the dispersal mode of the taxa considered. 


\section{SUMMARY}

The expansion of global croplands, plantations and pastures in the last decades, which led to a dramatic change in the spatial structuring of agricultural landscapes is one of the main drivers of biodiversity loss. Intensified agriculture, e.g. increased use of agrochemicals, on a local scale and simplification of landscapes on a regional scale were accompanied by a dramatic loss of biodiversity in European agricultural landscapes. However, the relative importance of local and regional drivers differs between taxa and habitats.

Although belowground biodiversity is an important and integrative part of the agroecosystem, studies on the interacting effects of local and landscape intensification on bacteria, collembolans and earthworms, which are important belowground detritivores, community are lacking. Current knowledge suggests that soil communities are highly resistant to anthropogenic disturbances due to the enormous functional redundancy in belowground food webs, although effects of agricultural intensification on belowground biota are not as predictable as effects on aboveground biota and need further study.

The first part of the thesis deals with effects of agricultural intensification on both aboveand belowground communities. We analysed the diversity of vascular plants, carabid beetles and birds in agricultural landscapes at the scale of plots in cereal fields $(n=1350)$, farms $(n=270)$, and European regions $(n=9)$. We partitioned diversity into its additive components $\alpha, \beta$, and $\gamma$, and assessed the relative contribution of $\beta$-diversity to total species richness at each spatial scale. Agricultural intensification was categorized into low, medium and high levels by calculating pesticide and fertilizer inputs as well as tillage operations. Agricultural intensification negatively affected the species richness of plants and birds, but not carabid beetles, at all spatial scales. Local agricultural intensification was closely related to $\beta$-diversity on larger scales up to the farm and region level, and thereby an indicator of farm and region wide biodiversity losses. $\beta$-diversity at the scale of farms (13-21\%) and regions (68\%-80\%) accounted for the major part of the total species richness for all three taxa, indicating great dissimilarity in environmental conditions on larger scales. For plants, relative importance of $\alpha$-diversity decreased with agricultural intensification, while relative importance of $\beta$-diversity on the farm scale increased with agricultural intensification for carabids and birds. Hence, agricultural intensification does

not necessarily homogenize local communities, presumably due to the heterogeneity of farming practices.

We sampled diversity and abundance of earthworms and collembolans, soil respiration rate 
and microbial biomass in 12 pairs of organically and conventionally managed winter wheat fields in landscapes differing in structural complexity to investigate interacting effects of agricultural intensification on local and landscape scales on belowground biota. Results show that only the in-field abundance of collembolans was slightly enhanced under organic farming, in contrast, soil respiration rate was higher under conventional management. Landscape simplification increased microbial biomass carbon in organically managed fields and decreased it in conventionally managed fields. As the same pattern was found for earthworm species richness, earthworms may have enhanced microbial biomass. In general, organic farming appears to be more efficient in conserving aboveground than belowground diversity.

In the second part of the thesis we studied the relative importance of spatial and environmental factors for the community composition of belowground biota. The relative importance of environmental or spatial processes determines whether communities are mainly formed by species-environment interactions or dispersal events, as outlined in the metacommunity concept, where dispersal events are important for maintaining biodiversity. In soils as very patchy, complex and poorly connected habitats, dispersal might shape the community composition more strongly than in less complex and better connected habitats.

We used a variance partitioning approach to investigate the relative importance of environmental conditions and spatial distances for soil bacterial, collembolan, carabid beetle and earthworm community composition in agricultural fields and old set-aside fallows, comparing samples from a very small scale of $40 \mathrm{~m}$ with samples from a regional scale of up to $13 \mathrm{~km}$. We found that environmental conditions, most notably $\mathrm{pH}$ and soil nitrate content, are important drivers of soil bacterial community composition. In addition, the spatial distribution of our sampling sites also influenced bacterial community composition, indicating a certain degree of provincialism, probably caused by dispersal limitation even on very small scales. However, our analysis also indicates that environmental factors are more important than space. The macroorganism taxa studied showed different patterns depending on their average body size. The larger macroorganisms did not show any spatial signals on the local scales. In contrast, their spatial signal is most prominent on the regional scale, while smaller macroorganisms, i.e. collembola, showed a spatial signal on the local but not on the regional scale. Differences 
between bacteria and macroorganisms are likely to be due to different dispersal modes for bacteria and macroorganisms in soils.

We conclude that agricultural intensification had negative effects on most of the studied aboveground taxa, with detrimental effects acting over multiple spatial scales. In contrast, organic farming appears to be more efficient in conserving aboveground than belowground diversity, which could be due to the enormous functional redundancy of the belowground community and therefore high resilience and resistance to anthropogenic disturbances. However, landscape context played a significant role in interaction with local management, emphasizing the importance of agri-environmental schemes designed for local and regional scales alike. The relative importance of environmental and spatial factors for soil communities appeared to depend on the dispersal mode of the taxa considered. 


\section{ACKNOWLEDGEMENTS}

First of all I thank my supervisors Prof. Dr. Teja Tscharntke, Dr. Carsten Thies and Dr. Till Eggers for interesting scientific discussions, critical advice and their support in general! Furthermore I thank Prof. Dr. Stefan Vidal and Prof. Dr. Matthias Schaefer for being part of my thesis committee. Funding was kindly granted by the German Research Foundation within the framework of the Biolog programme.

I am grateful to Antje Möhlmeyer for bearing with my need of refrigerator space and for help in the lab. I thank Jutta Gilles for help concerning all matters of administrative stuff and Christoph Scherber for valuable statistical advice.

I owe special thanks to the Agroecology group for creating such a nice working atmosphere and the great time I had in Göttingen during the last three years. I would also like to thank the Experimental Ecology group in Osnabrück for many interesting and funny coffee breaks.

I am grateful to the members of the Agripopes project for the good collaboration and a lot of captivating and enjoyable meetings.

Finally, I am extremely grateful to my family and Sarah for their everlasting support! 


\section{Curriculum Vitae}

Andreas Flohre, born 09.10.1980 in Ostercappeln, Germany

$4 / 2007-4 / 2010$

Georg-August-University Göttingen, Germany, Biodiversity and Ecology, $\mathrm{PhD}$

$12 / 2006$

Diploma thesis, Department of Ecology, Experimental Ecology, University Osnabrück. Title: "The influence of Collembola (Insecta) and enhanced nitrogen deposition (ammonium nitrate) on Rhytidiadelphus squarrosus (Hedw.) Warnst. (Hylocomiaceae)"

$2005-1 / 2007$

Employment as Hilfswissenschaftler (assistant) in teaching, Department of Botany, and research (laboratory work), Department of Ecology, University of Osnabrück

$2001-2006$

Study of Biology at the University of Osnabrück with main focus on Botany, Ecology and Biophysics

2000

Abitur at the Johannes Kepler Gymnasium in Ibbenbüren, Germany

Publication list 
Articles and book chapters:

Flohre, A., Fischer, C., Aavik, T., Bengtsson, J., Berendse, F., Bommarco, R., Ceryngier, P., Clement, L.W., Dennis, C., Eggers, S., Emmerson, M., Geiger, F., Guerrero, I., Hawro, V., Inchausti, P., Liira, J., Morales, M.B., Oñate, J.J., Pärt, T., Weisser, W., Winqvist, C., Thies, C. \& Tscharntke, T. (submitted). Agricultural intensification and biodiversity partitioning across European landscapes comparing plants, carabid beetles and birds.

Flohre, A., Rudnick, M., Traser, G., Tscharntke, T. \& Eggers, T. (submitted). Spatial scale predicts the distribution of soil biota: a community approach

Flohre, A., Rudnick, M., Traser, G., Tscharntke, T. \& Eggers, T. (submitted). Does soil biota benefit from organic farming in complex vs. simple landscapes?

Rudnick, M., Flohre, A., Tscharntke, T. \& Eggers, T. (in preparation). Landscape does not predict microbial community composition and diversity.

Logue, J. B., Peter, H., Declerck, P., Flohre, A., Gantner, S., Gülzow, N., Hörtnagl, P., Meier, S., Mouquet, N., Pecceu, B. \& Hillebrand, H. (in preparation). Empirical approaches to metacommunities - a review and comparison to theory.

Fischer, C., Flohre, A., Clement, L.W., Batáry, P., Weisser, W.W., Tscharntke, T. \& Thies, C. (submitted). Landscape structure versus farming practices as predictors of bird diversity during breeding season and in winter.

Geiger, F., Bengtsson, J., Berendse, F., Weisser, W.W., Emmerson, M., Morales, M.B., Ceryngier, P., Liira, J., Tscharntke, T., Winqvist, C., Eggers, S., Bommarco, R., Pärt, T., Bretagnolle, V., Plantegenest, M., Clement, L.W., Dennis, C., Palmer, C., Oñate, J.J., Guerrero, I., Hawro, V., Aavik, T., Thies, C., Flohre, A., Hänke, S., Fischer, C., Goedhart, P.W. \& Inchausti, P. (2010). Persistent negative effects of pesticides on 
biodiversity and biological control potential on European farmland. Basic and Applied Ecology, 11, 97-105.

Geiger, F., Berendse, F., de Snoo, G.R., Guerrero, I., Morales, M.B., Oñate, J.J., Eggers, S., Pärt, T., Bommarco, R., Bengtsson, J., Clement, L.W., Weisser, W.W., Dennis, C., Emmerson, M., Olszewski, A., Ceryngier, P., Hawro, V., Liira, J., Fischer, C., Flohre, A., Thies, C. \& Tscharntke, T. (submitted). Mixed responses of farmland birds to agricultural intensification across Europe.

Geiger, F., de Snoo, G.R.., Berendse, F., Guerrero, I., Morales, M.B.., Oñate, J.J., Eggers, S., Pärt, T., Bommarco, R., Bengtsson, J., Clement, L.W., Weisser, W.W., Olszewski, A., Ceryngier, P., Hawro, V., Inchausti, P., Fischer, C., Flohre, A., Thies, C. \& Tscharntke, T. (in preparation). Farm management and landscape composition influence farmland birds in winter: a pan-European approach.

Winqvist, C., Bengtsson, J., Aavik, T., Berendse, F., Clement, L.W., Eggers, S., Fischer, C., Flohre, A., Geiger, F., Liira, J., Pärt, T., Thies, C., Tscharntke, T., Weisser, W.W. \& Bommarco, R. (in preparation). Farming practice and landscape complexity affect biodiversity and biological control potential across Europe.

C. Thies, D. Gabriel. I. Roschewitz, B. Waßmuth, A. Flohre and T. Tscharntke (in press). Ackerwildpflanzen-Diversität richtig managen - von Feldern, über Landscahften zu Regionen. In: S. Hotes and V. Wolters (eds) Fokus Biodiversität, Oekom Verlag, München.

C. Thies, J. Schreiber, A. Flohre, C. Fischer and T. Tscharntke (in press). Diversität, Produktivität und landwirtschftliche Intensivierung. In: S. Hotes and V. Wolters (eds) Fokus Biodiversität, Oekom Verlag, München.

\section{Conference Proceedings:}

Flohre, A., Fischer, C., Aavik, T., Bengtsson, J., Berendse, F., Bommarco, R., Ceryngier, P., Clement, L.W., Dennis, C., Eggers, S., Emmerson, M., Geiger, F., Guerrero, 
I., Hawro, V., Inchausti, P., Liira, J., Morales, M.B., Oñate, J.J., Pärt, T., Weisser, W., Winqvist, C., Thies, C. \& Tscharntke, T. (2009). Agricultural intensification and dispersal ability affect beta diversity of plants, carabids and birds. 2nd European Congress of Conservation Biology (ECCB), Prague, Czech Republic, 01 - 05 September 2009

\section{DECLARATION OF THE AUTHOR'S OWN CONTRIBUTION TO MANUSCRIPTS WITH MULTIPLE AUTHORS}

I am the overall author of all manuscripts presented in this thesis. I developed the main ideas, analysed the data and wrote the manuscripts. All co-authors helped finalising the manuscripts. I did not use any other sources as the ones indicated in the chapters. This thesis has not been submitted previously in any form for another degree at any university or institution.

Göttingen, March 2010 